\title{
IT Spillover Effects on Korea Economy: for the Creative Economy based on IT
}

\author{
Yong Jae Shin ${ }^{1}$ and Myung-Seong Yim ${ }^{2 *}$ \\ 'Graduate School of Global e-Governance, Inha University, Incheon Korea; \\ yjidea@inha.ac.kr \\ 2Department of Business Administration, Sahmyook University, Seoul Korea; \\ msyim@syu.ac.kr
}

\begin{abstract}
Objectives: The studies in the unit of nation revealed that the IT productivity is in the course of influencing GDP. Therefore, this study analyzed the TFP (Total Factor Productivity) of IT hardware and IT service industries and their productivity spillover effect on each industry. Methods/Statistical Analysis: This study used linked input-output tables to reclassify the IT industry into IT hardware and IT service, obtained the TFP of the IT hardware and IT service, and analyzed the effect of each TFP on other industries. In this way, unlike conventional labor productivity based IT productivity, it was possible to obtain TFP and price-based qualitative numerical values in terms of the productivity effect on other industries. Findings: According to the analysis, the TFP of IT hardware was 2.313 in 2000 and 3.906 in 2005, which was the highest of the TFPs of 30 industries. The TFP of IT service was 0.990 in 2000 which was the 11th position, and 0.988 in 2005 which was the 8th position. Application/Improvements: The study results bring about the following suggestions: First, the productivity of the IT industry positively influenced the Korean economy, and the influence was on the rise. Secondly, the spillover effect of the IT industry expanded from the secondary industry to the tertiary industry. The effect of IT hardware on the tertiary industry was also charged greatly in terms of importance. Thirdly, the IT industry evenly influenced overall industries, rather than particular industries, with the lapse of time.
\end{abstract}

Keywords: Input-Output Analysis, Information Technology Hardware, Information Technology Productivity, Information Technology Service Total Factor Productivity

\section{Introduction}

In 1987, Solow created the term of Information Technology Productivity Paradox meaning that the use of information technology fails to influence productivity. Since then, the dispute over the value of information technology use has been activated. Unlike IT ROI (Return On Investment), IT productivity uses production function and is related to the effect of IT capital stock on per capita gross product. Solow ${ }^{1}$ suggested that information technology failed to influence gross product and his suggestion greatly impacted the IT industry and enterprises. In the 1990s, theses that opposed or supported his argument have triggered the dispute actively. Still, relevant theses by industry, by detailed area, and by nation have been published so far.

A previous study supports the IT productivity paradox . They analyzed manufacturers in the US and came to the conclusion that IT investments failed to influence gross product. In addition, there have been many analyses on the service industry, among which Strassman analyzed 38 service enterprises and revealed that there was no correlation between IT ratio and performance, and a researcher reported that IT ROI was only $60 \%$ of performance ${ }^{3}$. However, the previous study ${ }^{3}$

${ }^{*}$ Author for correspondence 
pointed out the mistakes of previous study results and presented that IT investments positively influenced productivity. The typical thesis related to such argument is introduced by another researcher ${ }^{4}$ who studied the topic in the unit of enterprise and of industry. Aside from that, many studies have been conducted on the IT productivity of enterprises or industries in a country. $\mathrm{In}^{5,6}$ researched the IT productivity in the unit of country and looked into the effect on GDP per laborer, and presented that IT capital stock per laborer positively influenced GDP.

The dispute over IT productivity paradox seemed to be wrapped up. However, with the development of IT, enterprises use IT in various ways, including IT specification, new forms of connection, creation of new industries, and tool for corporate innovation, beyond the past simple labor replacement and productivity improvement. The phenomenon was proved by the fact that IT investments in mid-2000 accounted for over $50 \%$ of all corporate investments. Accordingly, there has been more curiosity of the economic spillover effect of IT. Therefore, since 2000s, theses related to IT productivity have been more diversified by focusing on the effect of specified IT technology, the effect of IT workers, the effect of the intensification extent of IT application, and studies on the spillover effect of IT in firms $\frac{7-10}{}$.

However, most studies have been conducted in the unit of enterprise. The studies in the unit of nation revealed that the IT productivity is in the course of influencing GDP. Therefore, this study used linked input-output tables to reclassify the IT industry into IT hardware and IT service, obtained the TFP (Total Factor Productivity) of the IT hardware and IT service, and analyzed the effect of each TFP on other industries. In this way, unlike conventional labor productivity based IT productivity, it was possible to obtain TFP and price-based qualitative numerical values in terms of the productivity effect on other industries.

\section{Data}

The input-output table used in the analysis has the following features. Input-output analysis is a qualitative method to analyze inter-industry correlation, first used by Leontief in his study of input-output relations in the US economy ${ }^{11-13}$. The analysis involves an input-out table whose columns show the input structure (i.e. the composition of production costs spent by each sector) and rows indicate the output structure (i.e. how much output of each industrial sector was utilized to satisfy intermediate or final demand of various sectors).

The Table 1 shows the basic structure of input-output table, which is divided into endogenous and exogenous sections. Endogenous section records intermediate demand and intermediate input, which represent interaction and trade among producers of goods and services. On the other hand, exogenous sector records final demand and value added. As values of exogenous sector are determined by factors external to the model, the values of endogenous sector are automatically determined by the model accordingly. This makes endogenous sector the most important data for analysis and interpretation.

Input and output structures can be calculated via following equations.

Input structure $=$ gross input + intermediate input + value added

Output structure $=$ (intermediate demand + final demand) - revenue

Total demand (= total supply)

Total input $=$ Total production

Table 1. Input-output table structure

\begin{tabular}{|c|c|c|c|c|c|c|c|c|c|c|}
\hline \multicolumn{2}{|l|}{ endogenous sector } & \multicolumn{6}{|c|}{ Intermediate demand } & \multirow{2}{*}{$\begin{array}{c}\text { Total demand } \\
\mathrm{Y} 1\end{array}$} & \multirow{2}{*}{$\begin{array}{c}\text { Import (exemption) } \\
\text { M1 }\end{array}$} & \multirow{2}{*}{$\begin{array}{c}\text { Total Output } \\
\mathrm{X} 1\end{array}$} \\
\hline intermediate input & 1 & $\begin{array}{c}2 \\
\mathrm{x} 11\end{array}$ & . & $\cdot$ & . & n & $\mathrm{x} \ln$ & & & \\
\hline & 2 & $\mathrm{x} 21$ & $\mathrm{x} 22$ & . & & . & $\mathrm{x} 2 \mathrm{n}$ & $\mathrm{Y} 2$ & M2 & $\mathrm{X} 2$ \\
\hline & . & . & . & . & . & . & . & . & . & . \\
\hline & . & . & . & . & . & . & . & . & . & . \\
\hline & . & . & . & . & . & . & . & . & . & . \\
\hline & $\mathrm{n}$ & $\mathrm{xn} 1$ & $\mathrm{xn} 2$ & . & . & . & $\mathrm{xnn}$ & Yn & $\mathrm{Mn}$ & $\mathrm{Xn}$ \\
\hline \multicolumn{2}{|l|}{ Value Added } & $\mathrm{V} 1$ & $\mathrm{~V} 2$ & . & . &. & $\mathrm{Vn}$ & \multirow{2}{*}{\multicolumn{3}{|c|}{ exogenous sector }} \\
\hline \multicolumn{2}{|l|}{ Total input } & $\mathrm{X} 1$ & $\mathrm{X} 2$ & . & . & $\cdot$ & $\mathrm{Xn}$ & & & \\
\hline
\end{tabular}


The aim of this research is to investigate spillover effects of IT production on production in other sectors of economy, by carrying out input-output analysis the data for the analysis were obtained from the input-output table at constant price for years 2005, 2000 and 1995, published by the Bank of Korea in 2009플. The input-output table at constant price neglects effects of price fluctuation, and hence assesses economic growth and changes in industrial structure by the amount of output. This makes it suitable for analysis of qualitative changes in the industrial structure and production technology and well as for identification of individual contribution to economic growth by each factor, such as consumption, investment, export, import substation and technological advancement $\frac{11,14}{}$. For TFP analysis, the base year for price level was readjusted from 2005 to 1995, by reverse-calculating the adjustments made in the original input-output table, where the base year was 2005 .

For the purpose of this paper, IT industry was divided into IT hardware industry and IT service industry to investigate how productivity gain in each industry affects other industries. Table 2, further classification yielded 12 sectors for IT hardware, all of them under larger-sized sector 13, "electronic and electrical equipment", and 2 sectors of IT service, derived from larger-sized sector 24, "business service". The classification system was constant for years 1995 to 2005. Later, IT hardware and IT service were classified as larger-sized sectors on their own, occupying larger-sized sectors 29 and 30, respectively.

Table 2. Classification of IT Hardware and IT service

\begin{tabular}{|l|l|l|l|}
\hline \multicolumn{4}{|c|}{ IT Hardware Sector1995 2005 } \\
\hline 1 & Electric transformers & 7 & Integrated circuits \\
\hline 2 & $\begin{array}{l}\text { Insulated wires and } \\
\text { cables }\end{array}$ & 8 & $\begin{array}{l}\text { Electric resistors and } \\
\text { storagebatteries }\end{array}$ \\
\hline 3 & Batteries & 9 & Electric coils, transformers \\
\hline 4 & Electron tubes & 10 & Printed circuit boards \\
\hline 5 & Digital display & 11 & Misc. electronic components \\
\hline 6 & $\begin{array}{l}\text { Semiconductor } \\
\text { devices }\end{array}$ & 12 & $\begin{array}{l}\text { Computer and peripheral } \\
\text { equipment }\end{array}$ \\
\hline \multicolumn{4}{|c|}{ IT Service Sector 1995-2005 } \\
\hline 1 & $\begin{array}{l}\text { Computer Services } \\
\text { development and } \\
\text { supply }\end{array}$ & 2 & Computer related services \\
\hline
\end{tabular}

Table 3 is industries of re-classification to analysis. IT industry located to 29sector of IT hardware and
IT service. So, IT industry is included in re-classified 30 industries.

Table 3. Exogenous specification of the IT Industry

\begin{tabular}{|c|c|c|c|}
\hline No & Name of Sector & No & Name of Sector \\
\hline 1 & $\begin{array}{l}\text { Agriculture, forestry } \\
\text { and fishing }\end{array}$ & 16 & $\begin{array}{l}\text { Furniture and other } \\
\text { manufactured products }\end{array}$ \\
\hline 2 & Mining and quarrying & 17 & $\begin{array}{l}\text { Electricity, gas, steam } \\
\text { and water supply }\end{array}$ \\
\hline 3 & $\begin{array}{l}\text { Food, beverages and } \\
\text { tobacco products }\end{array}$ & 18 & Construction \\
\hline 4 & Textile and apparel & 19 & $\begin{array}{l}\text { Wholesale and retail } \\
\text { trade }\end{array}$ \\
\hline 5 & $\begin{array}{l}\text { Wood and paper } \\
\text { products }\end{array}$ & 20 & $\begin{array}{l}\text { Accommodation and } \\
\text { food services }\end{array}$ \\
\hline 6 & $\begin{array}{l}\text { Printing and } \\
\text { reproduction of } \\
\text { recorded media }\end{array}$ & 21 & Transportation \\
\hline 7 & $\begin{array}{l}\text { Petroleum and coal } \\
\text { products }\end{array}$ & 22 & $\begin{array}{l}\text { Communications and } \\
\text { broadcasting }\end{array}$ \\
\hline 8 & $\begin{array}{l}\text { Chemicals, drugs and } \\
\text { medicines }\end{array}$ & 23 & Finance and insurance \\
\hline 9 & $\begin{array}{l}\text { Non-metallic mineral } \\
\text { products }\end{array}$ & 24 & $\begin{array}{l}\text { Real estate and business } \\
\text { services }\end{array}$ \\
\hline 10 & Basic metal products & 25 & $\begin{array}{l}\text { Public administration } \\
\text { and defense }\end{array}$ \\
\hline 11 & $\begin{array}{l}\text { Fabricated metal } \\
\text { products except } \\
\text { machinery and } \\
\text { furniture }\end{array}$ & 26 & $\begin{array}{l}\text { Education, health and } \\
\text { social work }\end{array}$ \\
\hline 12 & $\begin{array}{l}\text { General machinery } \\
\text { and equipment }\end{array}$ & 27 & Other services \\
\hline 13 & $\begin{array}{l}\text { Electronic and } \\
\text { electrical equipment }\end{array}$ & 28 & Dummy sectors \\
\hline 14 & Precision instruments & 29 & IT Hardware \\
\hline 15 & $\begin{array}{l}\text { Transportation } \\
\text { equipment }\end{array}$ & 30 & IT Service \\
\hline
\end{tabular}

\section{Methodology}

Productivity can be measured as PFP (Partial Factor Productivity) or TFP (Total Factor Productivity).

$$
\begin{aligned}
& \mathrm{PFP}_{\mathrm{i}}=\frac{\mathrm{y}}{\mathrm{x}_{1}} \\
& \mathrm{TFP}=\frac{\mathrm{y}}{\left.\mathrm{\nabla X}(\mathrm{x}]_{1}\right)}
\end{aligned}
$$


PFP represents the output per unit of a specific factor input, such as labor productivity, capital productivity and raw material productivity. Out of these, labor productivity is an important determiner of employment rate and quality of life. PFP is relatively, but a crucial disadvantage of being unrelated to efficiency of production process as a whole ${ }^{\frac{12}{2}}$.

On the other hand, TFP represents the output per unit of all factor inputs involved in the production process. Equation 2 poses a problem when calculating TFP as $\mathrm{X}\left(\mathrm{x}_{\mathrm{i}}\right)$ is the total input factor, an aggregate of all factors.

$$
\begin{aligned}
\mathrm{TFP} & =\frac{\mathrm{y}}{\sum \omega_{\mathrm{i}} \mathrm{x}_{1}} \\
\mathrm{TFP} & =\frac{\mathrm{y}}{\Pi \mathrm{x}_{\mathrm{i}}^{\alpha_{1}}}, \quad \sum \alpha_{1},
\end{aligned}
$$

Two approaches have been evolved to approach this problem. Kendrick's solution, shown in equation (3), calculates the arithmetic mean of the quantity of factor inputs by using the price of each factor. On the other hand, Solow's approach, shown in equation (4), is to calculate the geometric mean by assessing contribution of each factor to total cost.

In relation to each industrial sector in INPUTOUTPUT TABLE, the output is the total national output $\left(\mathrm{X}_{\mathrm{j}}\right)$ and factor inputs are labor, capital $\left(\mathrm{v}_{\mathrm{kj}} \mathrm{X}_{\mathrm{j}}\right)$, and intermediary goods $\left(\alpha_{i j} X_{i}\right)$.

$$
\operatorname{TFP}_{\mathrm{j}}=\frac{\mathrm{y}}{\sum \alpha_{\mathrm{ij}} \mathrm{X}_{\mathrm{i}}+\sum \mathrm{v}_{\mathrm{kj}} \mathrm{X}_{\mathrm{j}}}=\frac{1}{\sum \boldsymbol{\alpha}_{\mathrm{ij}} \sum \mathrm{v}_{\mathrm{kj}}}
$$

Productivity analysis with INPUT-OUTPUT TABLE involves identifying input-output relationship within a time period shown in each row of the INPUT-OUTPUT TABLE. Applying this to industry A, the target industry, following equations are obtained.

$$
\begin{aligned}
& \sum_{i} p_{i}^{o} q_{i}^{o}-\sum_{j} w_{j}^{o} f_{j}^{\circ} \\
& \sum_{i} p_{i}^{t} q_{i}^{t}-\sum_{i} w_{j}^{t} f_{j}^{t}
\end{aligned}
$$

$i(=1, \ldots, n)$ represents product types and $j(=1, \ldots ., m)$ represents input factor types. Price of products and quantity produced are denoted by $\mathrm{p}$ and q, respectively. Lastly, $\mathrm{w}$ and $\mathrm{f}$ denote the price of input factors and quantity required, respectively. However, since productivity gain is measured in terms of real change in quantity, base-year measures of absolute productivity, measured at constant price at any point time, $t$, is expressed as following.

$$
\pi_{\mathrm{A}}=\frac{\sum \mathrm{p}_{\mathrm{i}}^{\circ} \mathrm{q}_{\mathrm{i}}^{\mathrm{t}}}{\sum \mathbf{w}_{\mathrm{j}}^{\mathrm{o}} \mathrm{f}_{\mathrm{j}}^{\mathrm{o}}}
$$

This can be converted to represent productivity gain in concrete price terms as in equation (9). By combining (6), (7) and (9) other equations can be derived.

$$
s_{A}=\sum_{i} p_{i}^{\circ} q_{i}^{t}-\sum_{j} w_{j}^{\circ} f_{j}^{t}
$$

$$
\begin{aligned}
& \mathrm{S}_{\mathrm{A}}=\left(\sum_{\mathrm{i}} \mathrm{I} \mathrm{p}_{\mathrm{i}}^{\circ} \mathrm{q}_{\mathrm{i}}^{\mathrm{t}}-\sum_{j} \mathrm{w}_{\mathrm{j}}^{\circ} \mathrm{f}_{\mathrm{j}}^{\mathrm{t}}\right)-\left(\sum_{\mathrm{i}} \mathrm{p}_{\mathrm{i}}^{\circ} \mathrm{q}_{\mathrm{i}}^{\circ}-\sum_{j} \mathrm{w}_{\mathrm{j}}^{\circ} \mathrm{f}_{\mathrm{j}}^{\circ}\right) \mathrm{I} \\
& \left.=\sum_{i} p_{i}^{\circ} \mathbf{z}(\mathbf{p}]_{i}^{t}-q_{i}^{\circ}\right)-\sum_{j}\left[w_{j}^{\circ}\left(f_{j}^{t}-f_{j}^{\circ}\right]\right)
\end{aligned}
$$

$\mathrm{s}_{\mathrm{A}}=\left(\sum_{\mathrm{i}} \underline{\mathrm{z}} \mathrm{p}_{\mathrm{i}}^{\mathrm{o}} \mathrm{q}_{\mathrm{i}}^{\mathrm{t}}-\sum_{\mathrm{j}} \mathrm{w}_{\mathrm{j}}^{\mathrm{o}} \mathrm{f}_{\mathrm{j}}^{\mathrm{t}}\right)-\left(\sum_{\mathrm{i}} \mathrm{p}_{\mathrm{i}}^{\mathrm{t}} \mathrm{q}_{\mathrm{i}}^{\mathrm{t}}-\sum_{j} \mathrm{w}_{\mathrm{j}}^{\mathrm{t}} \mathrm{f}_{\mathrm{j}}^{\mathrm{t}}\right) \mathbf{I}$

$$
=-\sum_{i} p_{i}^{t} \bar{I}\left(p \rrbracket_{i}^{t}-q_{i}^{\circ}\right)-\sum_{j} \nabla f_{j}^{t}\left(w_{j}^{t}-w_{j}^{o} \rrbracket\right)
$$

Equation (10) shows productivity gain from one point of time to another, and (11) explains productivity gain in terms of price changes. It shows that productivity gained between two points of time at equilibrium affects product price of industry a, which redistributes the productivity gain via spillover effects and change in price of original factor inputs.

This effect, applied to industry $j$ through input coefficient of input-output analysis, allows conversion of equations (6) to (11) into following equations.

$$
\mathrm{X}_{\mathrm{j}, \mathrm{o}}^{(\mathrm{o})}=\sum_{\mathrm{i}} \mathrm{a}_{\mathrm{ij}, \mathrm{o}}^{(\mathrm{o})} \mathrm{X}_{\mathrm{j}, \mathrm{o}}^{(\mathrm{o})}-\sum_{\mathrm{i}} \mathrm{v}_{\mathrm{kj}, \mathrm{o}}^{(\mathrm{o})} \mathrm{X}_{\mathrm{j}, \mathrm{o}}^{(\mathrm{o})}
$$




$$
\begin{aligned}
& \mathrm{X}_{\mathrm{j}, \mathrm{t}}^{(\mathrm{t})}=\sum_{\mathrm{i}} \mathrm{a}_{\mathrm{ij}, \mathrm{t}}^{(\mathrm{t})} \mathrm{X}_{\mathrm{j}, \mathrm{t}}^{(\mathrm{t})}-\sum_{\mathrm{i}} \mathrm{v}_{\mathrm{kj}, \mathrm{t}}^{(\mathrm{t})} \mathrm{X}_{\mathrm{j}, \mathrm{t}}^{(\mathrm{t})} \\
& \pi_{\mathrm{j}}=\frac{\mathrm{X}_{\mathrm{j}, \mathrm{t}}^{(0)}}{\sum_{\mathrm{i}} \mathrm{a}_{\mathrm{ij}, \mathrm{t}}^{(0)} \mathrm{X}_{\mathrm{j}, \mathrm{t}}^{(0)}+\sum_{\mathrm{k}} \mathrm{v}_{\mathrm{kj}, \mathrm{o}}^{(0)} \mathrm{X}_{\mathrm{j}, \mathrm{t}}^{(0)}}
\end{aligned}
$$

$$
\mathrm{S}_{\mathrm{j}, \mathrm{t}}=\mathrm{X}_{\mathrm{j}, \mathrm{t}}^{(\mathrm{o})}-\sum_{\mathrm{i}} \mathrm{a}_{\mathrm{ij}, \mathrm{t}}^{(\mathrm{o})} \mathrm{X}_{\mathrm{j}, \mathrm{t}}^{(\mathrm{o})}-\sum_{\mathrm{k}} \mathrm{v}_{\mathrm{k}, \mathrm{t}, \mathrm{t}}^{(\mathrm{o})} \mathrm{X}_{\mathrm{j}, \mathrm{t}}^{(\mathrm{o})}
$$

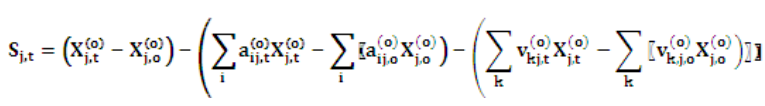

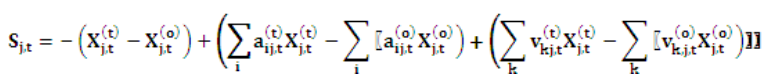

Understanding of the above set of equations is aided by the fact that the basic presumption of input-output analysis is that production in any one sector consists of homogenous product $\frac{12}{12} .0$ and $t$ indicate time of price evaluation, while $\mathrm{a}_{\mathrm{ij}}$ represents technical coefficients of intermediary goods and $\mathrm{v}_{\mathrm{kj}}$ represents value-added coefficients of original input factors on the INPUT-OUTPUT TABLE.

As the primary aim of this research is to investigate how price change induced by productivity gain affects productivity in other industrial sectors, only equation (17) will be considered.

The equation shows how productivity gain in sector $\mathrm{j}$ is redistributed to other economic sectors, and the next variable shows the benefit gained by sector $j$ from price changed in other sectors. In other words, productivity gain in a specific sector directly reduces costs of the same sector, and this in turn lowers the price of its product, thereby the whole economy experiences lowered costs $\frac{15,16}{}$.

\section{Result}

\subsection{Analysis of Productivity Gain}

Productivity gain for each industrial sector was analyzed by applying equations (8) and (9) to the data from INPUT-OUTPUT TABLE for 1995, 2000 and 2005. The table shows the TFP changes in each sector and their effects with 1995 as base year. IT hardware industry showed TFP gain of 2.313 in 2000 and 3.9060 in 2005 which was the highest of all industries in each year. IT service fared worse with TFP gain of 0.990 in 2000 and 0.9880 in 2005 , ranking at 11 th and 8 th place respectively (Tables 4 and 6).

The Tables 4-6 divides productivity gain into its component factors and shows price change in product, intermediary goods, labor and capital as well as economic gains from productivity gain. In 2000, IT hardware experienced rise in price of intermediary goods, labor and capital by 9,804,949, 5,565,290 and 13,049,873, respectively. Yet, the price of product has fallen due to productivity gain. In numeric terms, price of total input for the whole economy is $47,986,539$, and productivity gain mounts to $76,406,650$.

In 2005, price of intermediary goods has fallen by 2,987,965 while prices of labor and capital have risen by $3,182,375$, and $5,270,293$. Again, total rise in price of input has been cancelled out by productivity gain, and product price has fallen. In numerical terms, productivity has increased by $286,391,295$ and price of total input was 280,926,591(Tables 6,7).

On the other hand, IT Service industry was less successful with TFP lower than 1 for both years 2000 and 2005. In 2000, price of all inputs rose and productivity gain was calculated to be $-93,463$, resulting in price of total input of $-2,604,164$ (Table 4). In 2005, price of all inputs rose again, and productivity changed by $-190,004$, while price of total input was $-5,799,013$, faring even worse than it had in 2000(Table 6).

\subsection{Analysis of Inter-industry Spillover Effects on Productivity}

The research also investigated how decline in product prices of IT industry due to productivity gain affected other industries. The table A-1 and Table 2 shows the inter-industrial distribution of productivity. Each row shows how much each industry affects other industries by price changes in its own product. Positive values denote a cost reduction and negative values denote cost increase. Each column represents how much cost change is incurred on each industry by price change in intermediary goods of other industries. For example, industry $i$ lowered costs of the entire economy by value $\mathrm{R}$, and in turn received cost reduction effect of value $\mathrm{C}$ from other industries.

By simultaneously considering economic spill over from productivity gains, shown in the previous Table. $4-5$, and the $\mathrm{R}$ value of this table, it can be determined 
Table 4. IT Service and Hardware TFP result (2000)

\begin{tabular}{|c|c|c|c|c|c|c|c|}
\hline No & Sector & TFP & Rank & $S$ & Total input & $\begin{array}{c}\text { Total } \\
\text { intermediate } \\
\text { input }\end{array}$ & $\begin{array}{c}\text { Total value } \\
\text { added }\end{array}$ \\
\hline 1 & Agriculture, forestry and fishing & 0.978 & 16 & $-807,856$ & $3,893,071$ & $3,174,882$ & $-89,667$ \\
\hline 2 & Mining and quarrying & 0.973 & 18 & $-67,633$ & 210,969 & 255,461 & $-112,125$ \\
\hline 3 & $\begin{array}{l}\text { Food, beverages and tobacco } \\
\text { products }\end{array}$ & 0.961 & 21 & $-1,971,627$ & $10,782,852$ & $5,866,657$ & $2,944,568$ \\
\hline 4 & Textile and apparel & 1.001 & 8 & 43,725 & $6,508,035$ & $3,682,460$ & $2,869,299$ \\
\hline 5 & Wood and paper products & 0.939 & 24 & $-852,680$ & $3,674,373$ & $2,187,684$ & 634,010 \\
\hline 6 & $\begin{array}{l}\text { Printing and reproduction of } \\
\text { recorded media }\end{array}$ & 0.985 & 14 & $-43,314$ & 899,213 & 537,513 & 318,386 \\
\hline 7 & Petroleum and coal products & 0.842 & 28 & $-4,499,801$ & $29,145,882$ & $13,032,603$ & $11,613,477$ \\
\hline 8 & Chemicals, drugs and medicines & 1.029 & 5 & $2,204,080$ & $9,866,840$ & $13,919,003$ & $-1,848,082$ \\
\hline 9 & Non-metallic mineral products & 0.893 & 26 & $-1,796,267$ & $2,177,020$ & $2,282,196$ & $-1,901,444$ \\
\hline 10 & Basic metal products & 0.937 & 25 & $-3,508,071$ & $7,157,144$ & $7,025,449$ & $-3,376,375$ \\
\hline 11 & $\begin{array}{l}\text { Fabricated metal products except } \\
\text { machinery and furniture }\end{array}$ & 0.987 & 13 & $-229,232$ & $3,378,230$ & $2,244,430$ & 904,568 \\
\hline 12 & $\begin{array}{l}\text { General machinery and } \\
\text { equipment }\end{array}$ & 0.971 & 19 & $-1,133,341$ & $5,698,087$ & $4,743,363$ & $-178,617$ \\
\hline 13 & $\begin{array}{l}\text { Electronic and electrical } \\
\text { equipment }\end{array}$ & 1.244 & 2 & $11,985,325$ & $-5,528,303$ & $5,205,498$ & $1,251,524$ \\
\hline 14 & Precision instruments & 1.040 & 4 & 230,566 & $1,062,310$ & $1,051,256$ & 241,619 \\
\hline 15 & Transportation equipment & 0.988 & 12 & $-856,745$ & $4,285,877$ & $7,854,813$ & $-4,425,681$ \\
\hline 16 & $\begin{array}{l}\text { Furniture and other } \\
\text { manufactured products }\end{array}$ & 0.591 & 30 & $-6,125,368$ & $1,159,362$ & $1,177,040$ & $-6,143,046$ \\
\hline 17 & $\begin{array}{l}\text { Electricity, gas, steam and water } \\
\text { supply }\end{array}$ & 0.753 & 29 & $-7,738,820$ & $7,849,573$ & $5,357,435$ & $-5,246,681$ \\
\hline 18 & Construction & 0.966 & 20 & $-2,389,836$ & $31,326,734$ & $8,562,722$ & $20,374,176$ \\
\hline 19 & Wholesale and retail trade & 0.997 & 10 & $-173,190$ & $7,938,693$ & $5,162,163$ & $2,603,341$ \\
\hline 20 & $\begin{array}{l}\text { Accommodation and food } \\
\text { services }\end{array}$ & 0.951 & 23 & $-2,022,787$ & $1,519,909$ & $4,091,648$ & $-4,594,526$ \\
\hline 21 & Transportation & 0.847 & 27 & $-7,651,073$ & $8,609,127$ & $9,945,033$ & $-8,986,979$ \\
\hline 22 & $\begin{array}{l}\text { Communications and } \\
\text { broadcasting }\end{array}$ & 1.085 & 3 & $2,937,752$ & $-3,996,913$ & $3,060,886$ & $-4,120,048$ \\
\hline 23 & Finance and insurance & 1.002 & 6 & 100,469 & $13,369,276$ & $4,673,331$ & $8,796,414$ \\
\hline 24 & Real estate and business services & 0.960 & 22 & $-4,907,243$ & $12,596,850$ & $7,518,145$ & 171,462 \\
\hline 25 & $\begin{array}{l}\text { Public administration and } \\
\text { defense }\end{array}$ & 1.001 & 7 & 47,077 & $9,251,967$ & $3,005,062$ & $6,293,982$ \\
\hline 26 & Education, health and social work & 0.975 & 17 & $-1,237,159$ & $14,008,121$ & $3,733,156$ & $9,037,806$ \\
\hline 27 & Other services & 0.979 & 15 & $-666,574$ & $5,534,617$ & $3,320,790$ & $1,547,253$ \\
\hline 28 & Dummy sectors & 1.000 & 9 & 954 & $4,109,844$ & $4,110,798$ & 0 \\
\hline 29 & IT Hardware & 2.313 & 1 & $76,406,650$ & $-47,986,539$ & $9,804,949$ & $18,615,162$ \\
\hline 30 & IT Service & 0.990 & 11 & $-93,463$ & $2,604,164$ & 587,447 & $1,923,254$ \\
\hline
\end{tabular}


Table 5. IT Service and Hardware elements of Input ratio result (2000)

\begin{tabular}{|c|c|c|c|c|c|}
\hline No & Sector & $\begin{array}{l}\text { Compensation of } \\
\text { employees }\end{array}$ & Capital & $\begin{array}{l}\text { Employment } \\
\text { rate }\end{array}$ & Capital rate \\
\hline 1 & Agriculture, forestry and fishing & $-303,891$ & 214,224 & 3.39 & -2.39 \\
\hline 2 & Mining and quarrying & $-15,226$ & $-96,898$ & 0.14 & 0.86 \\
\hline 3 & Food, beverages and tobacco products & 677,794 & $2,266,773$ & 0.23 & 0.77 \\
\hline 4 & Textile and apparel & $1,367,298$ & $1,502,001$ & 0.48 & 0.52 \\
\hline 5 & Wood and paper products & 284,283 & 349,727 & 0.45 & 0.55 \\
\hline 6 & Printing and reproduction of recorded media & 200,741 & 117,645 & 0.63 & 0.37 \\
\hline 7 & Petroleum and coal products & 933,870 & $10,679,607$ & 0.08 & 0.92 \\
\hline 8 & Chemicals, drugs and medicines & $-1,561,075$ & $-287,007$ & 0.84 & 0.16 \\
\hline 9 & Non-metallic mineral products & $-1,023,211$ & $-878,232$ & 0.54 & 0.46 \\
\hline 10 & Basic metal products & $-1,020,418$ & $-2,355,957$ & 0.30 & 0.70 \\
\hline 11 & $\begin{array}{l}\text { Fabricated metal products except machinery } \\
\text { and furniture }\end{array}$ & 619,550 & 285,018 & 0.68 & 0.32 \\
\hline 12 & General machinery and equipment & $-209,350$ & 30,733 & 1.17 & -0.17 \\
\hline 13 & Electronic and electrical equipment & $-671,976$ & $1,923,500$ & -0.54 & 1.54 \\
\hline 14 & Precision instruments & 103,130 & 138,489 & 0.43 & 0.57 \\
\hline 15 & Transportation equipment & $-1,632,035$ & $-2,793,646$ & 0.37 & 0.63 \\
\hline 16 & Furniture and other manufactured products & $-3,751,626$ & $-2,391,420$ & 0.61 & 0.39 \\
\hline 17 & Electricity, gas, steam and water supply & $-1,009,493$ & $-4,237,188$ & 0.19 & 0.81 \\
\hline 18 & Construction & $12,436,490$ & $7,937,687$ & 0.61 & 0.39 \\
\hline 19 & Wholesale and retail trade & $1,044,494$ & $1,558,847$ & 0.40 & 0.60 \\
\hline 20 & Accommodation and food services & $-2,782,305$ & $-1,812,221$ & 0.61 & 0.39 \\
\hline 21 & Transportation & $-5,286,839$ & $-3,700,140$ & 0.59 & 0.41 \\
\hline 22 & Communications and broadcasting & $-1,228,434$ & $-2,891,613$ & 0.30 & 0.70 \\
\hline 23 & Finance and insurance & $4,571,774$ & $4,224,640$ & 0.52 & 0.48 \\
\hline 24 & Real estate and business services & $3,843,877$ & $-3,672,416$ & 22.42 & -21.42 \\
\hline 25 & Public administration and defense & $4,499,956$ & $1,794,025$ & 0.71 & 0.29 \\
\hline 26 & Education, health and social work & $7,268,622$ & $1,769,184$ & 0.80 & 0.20 \\
\hline 27 & Other services & $1,011,142$ & 536,111 & 0.65 & 0.35 \\
\hline 28 & Dummy sectors & 0 & 0 & 0.00 & 0.00 \\
\hline 29 & IT Hardware & $5,565,290$ & $13,049,873$ & 0.30 & 0.70 \\
\hline 30 & IT Service & $1,288,130$ & 635,125 & 0.67 & 0.33 \\
\hline
\end{tabular}

(Unit: Million KRW) /total value added (Table 4)= capital (Table 5) + compensation of employees (Table 5) 
Table 6. IT Service and Hardware TFP result (2005)

\begin{tabular}{|c|c|c|c|c|c|c|c|}
\hline No & Sector & TFP & Rank & S & Total input & $\begin{array}{c}\text { Total } \\
\text { intermediate } \\
\text { input }\end{array}$ & $\begin{array}{l}\text { Total value } \\
\text { added }\end{array}$ \\
\hline 1 & Agriculture, forestry and fishing & 0.9649 & 18 & $-1,301,604$ & $7,134,557$ & $6,063,393$ & $-230,440$ \\
\hline 2 & Mining and quarrying & 0.9780 & 12 & $-58,556$ & 629,970 & 520,144 & 51,270 \\
\hline 3 & $\begin{array}{l}\text { Food, beverages and tobacco } \\
\text { products }\end{array}$ & 0.9789 & 10 & $-1,096,378$ & $21,163,855$ & $12,265,226$ & $7,802,251$ \\
\hline 4 & Textile and apparel & 0.9159 & 23 & $-3,410,664$ & $4,310,853$ & $4,757,436$ & $-3,857,247$ \\
\hline 5 & Wood and paper products & 0.9199 & 22 & $-1,320,034$ & $4,352,601$ & $2,645,017$ & 387,550 \\
\hline 6 & $\begin{array}{l}\text { Printing and reproduction of } \\
\text { recorded media }\end{array}$ & 0.9789 & 11 & $-93,771$ & $2,682,857$ & $1,219,824$ & $1,369,262$ \\
\hline 7 & Petroleum and coal products & 0.8226 & 25 & $-4,815,425$ & $54,373,162$ & $30,803,537$ & $18,754,200$ \\
\hline 8 & Chemicals, drugs and medicines & 0.9575 & 21 & $-4,507,886$ & $37,801,885$ & $43,149,443$ & $-9,855,444$ \\
\hline 9 & Non-metallic mineral products & 0.7450 & 28 & $-7,041,351$ & $3,193,564$ & $5,208,172$ & $-9,055,958$ \\
\hline 10 & Basic metal products & 0.7981 & 26 & $-17,078,242$ & $49,641,718$ & $41,584,155$ & $-9,020,678$ \\
\hline 11 & $\begin{array}{l}\text { Fabricated metal products except } \\
\text { machinery and furniture }\end{array}$ & 0.9822 & 9 & $-500,847$ & $15,920,526$ & $11,038,710$ & $4,380,969$ \\
\hline 12 & $\begin{array}{l}\text { General machinery and } \\
\text { equipment }\end{array}$ & 0.8488 & 24 & $-10,531,850$ & $10,506,926$ & $13,466,262$ & $-13,491,186$ \\
\hline 13 & $\begin{array}{l}\text { Electronic and electrical } \\
\text { equipment }\end{array}$ & 1.5733 & 2 & $52,201,860$ & $-57,124,526$ & $-1,287,839$ & $-3,634,826$ \\
\hline 14 & Precision instruments & 0.9718 & 15 & $-314,204$ & 623,795 & $1,332,752$ & $-1,023,161$ \\
\hline 15 & Transportation equipment & 0.9753 & 14 & $-2,935,218$ & $16,388,741$ & $21,763,395$ & $-8,309,872$ \\
\hline 16 & $\begin{array}{l}\text { Furniture and other manufactured } \\
\text { products }\end{array}$ & 0.5275 & 29 & $-10,617,544$ & $1,770,437$ & $2,439,681$ & $-11,286,788$ \\
\hline 17 & $\begin{array}{l}\text { Electricity, gas, steam and water } \\
\text { supply }\end{array}$ & 0.4302 & 30 & $-43,430,230$ & $13,601,409$ & $13,508,036$ & $-43,336,858$ \\
\hline 18 & Construction & 0.9581 & 20 & $-3,640,872$ & $67,384,042$ & $26,108,570$ & $37,634,600$ \\
\hline 19 & Wholesale and retail trade & 1.0041 & 4 & 339,939 & $22,733,215$ & $11,942,395$ & $11,130,759$ \\
\hline 20 & Accommodation and food services & 0.9628 & 19 & $-1,813,534$ & $9,753,087$ & $8,878,629$ & $-939,076$ \\
\hline 21 & Transportation & 0.7615 & 27 & $-17,957,333$ & $21,393,821$ & $20,839,108$ & $-17,402,621$ \\
\hline 22 & $\begin{array}{l}\text { Communications and } \\
\text { broadcasting }\end{array}$ & 1.1037 & 3 & $5,633,934$ & $-10,918,107$ & $6,277,512$ & $-11,561,686$ \\
\hline 23 & Finance and insurance & 1.0026 & 5 & 158,381 & $26,105,966$ & $8,861,893$ & $17,402,454$ \\
\hline 24 & Real estate and business services & 0.9651 & 17 & $-5,345,647$ & $35,815,004$ & $16,319,224$ & $14,150,132$ \\
\hline 25 & Public administration and defense & 1.0021 & 6 & 100,384 & $21,228,660$ & $6,312,869$ & $15,016,174$ \\
\hline 26 & Education, health and social work & 0.9651 & 16 & $-2,525,131$ & $45,803,329$ & $9,016,119$ & $34,262,079$ \\
\hline 27 & Other services & 0.9776 & 13 & $-1,000,819$ & $14,936,980$ & $7,266,933$ & $6,669,228$ \\
\hline 28 & Dummy sectors & 1.0000 & 7 & 1,084 & $9,852,958$ & $9,854,043$ & 0 \\
\hline 29 & IT Hardware & 3.9060 & 1 & $286,391,295$ & $-280,926,591$ & $-2,987,965$ & $8,452,668$ \\
\hline 30 & IT Service & 0.9880 & 8 & $-190,004$ & $5,799,013$ & $2,358,043$ & $3,250,966$ \\
\hline
\end{tabular}

(Unit: Million KRW) / S = - (Total input $)+($ Total intermediate input $)+($ Total Value added $)$ 
Table 7. IT Service and Hardware elements of Input ratio result (2005)

\begin{tabular}{|c|c|c|c|c|c|}
\hline No & Sector & $\begin{array}{l}\text { Compensation of } \\
\text { employees }\end{array}$ & Capital & Employment rate & $\begin{array}{l}\text { Capital } \\
\text { rate }\end{array}$ \\
\hline 1 & Agriculture, forestry and fishing & 58,137 & $-288,578$ & -0.25 & 1.25 \\
\hline 2 & Mining and quarrying & 10,017 & 41,253 & 0.20 & 0.80 \\
\hline 3 & $\begin{array}{l}\text { Food, beverages and tobacco } \\
\text { products }\end{array}$ & $1,790,866$ & $6,011,385$ & 0.23 & 0.77 \\
\hline 4 & Textile and apparel & $-1,755,802$ & $-2,101,445$ & 0.46 & 0.54 \\
\hline 5 & Wood and paper products & 17,569 & 369,981 & 0.05 & 0.95 \\
\hline 6 & $\begin{array}{l}\text { Printing and reproduction of } \\
\text { recorded media }\end{array}$ & 701,663 & 667,599 & 0.51 & 0.49 \\
\hline 7 & Petroleum and coal products & $1,142,347$ & $17,611,852$ & 0.06 & 0.94 \\
\hline 8 & Chemicals, drugs and medicines & $-4,377,995$ & $-5,477,449$ & 0.44 & 0.56 \\
\hline 9 & Non-metallic mineral products & $-3,720,273$ & $-5,335,685$ & 0.41 & 0.59 \\
\hline 10 & Basic metal products & $-3,759,047$ & $-5,261,631$ & 0.42 & 0.58 \\
\hline 11 & $\begin{array}{l}\text { Fabricated metal products except } \\
\text { machinery and furniture }\end{array}$ & $2,439,390$ & $1,941,578$ & 0.56 & 0.44 \\
\hline 12 & $\begin{array}{l}\text { General machinery and } \\
\text { equipment }\end{array}$ & $-7,591,395$ & $-5,899,791$ & 0.56 & 0.44 \\
\hline 13 & $\begin{array}{l}\text { Electronic and electrical } \\
\text { equipment }\end{array}$ & $-2,801,953$ & $-832,873$ & 0.77 & 0.23 \\
\hline 14 & Precision instruments & $-554,103$ & $-469,058$ & 0.54 & 0.46 \\
\hline 15 & Transportation equipment & $-3,510,571$ & $-4,799,301$ & 0.42 & 0.58 \\
\hline 16 & $\begin{array}{l}\text { Furniture and other } \\
\text { manufactured products }\end{array}$ & $-7,105,325$ & $-4,181,464$ & 0.63 & 0.37 \\
\hline 17 & $\begin{array}{l}\text { Electricity, gas, steam and water } \\
\text { supply }\end{array}$ & $-8,776,837$ & $-34,560,021$ & 0.20 & 0.80 \\
\hline 18 & Construction & $22,869,095$ & $14,765,505$ & 0.61 & 0.39 \\
\hline 19 & Wholesale and retail trade & $4,830,588$ & $6,300,171$ & 0.43 & 0.57 \\
\hline 20 & $\begin{array}{l}\text { Accommodation and food } \\
\text { services }\end{array}$ & $-499,879$ & $-439,197$ & 0.53 & 0.47 \\
\hline 21 & Transportation & $-7,497,422$ & $-9,905,199$ & 0.43 & 0.57 \\
\hline 22 & $\begin{array}{l}\text { Communications and } \\
\text { broadcasting }\end{array}$ & $-3,282,777$ & $-8,278,909$ & 0.28 & 0.72 \\
\hline 23 & Finance and insurance & $6,448,403$ & $10,954,052$ & 0.37 & 0.63 \\
\hline 24 & Real estate and business services & $11,770,780$ & $2,379,352$ & 0.83 & 0.17 \\
\hline 25 & $\begin{array}{l}\text { Public administration and } \\
\text { defense }\end{array}$ & $10,846,785$ & $4,169,389$ & 0.72 & 0.28 \\
\hline 26 & $\begin{array}{l}\text { Education, health and social } \\
\text { work }\end{array}$ & $27,154,691$ & $7,107,388$ & 0.79 & 0.21 \\
\hline 27 & Other services & $3,863,610$ & $2,805,618$ & 0.58 & 0.42 \\
\hline 28 & Dummy sectors & 0 & 0 & 0.00 & 0.00 \\
\hline 29 & IT Hardware & $3,182,375$ & $5,270,293$ & 0.38 & 0.62 \\
\hline 30 & IT Service & $2,184,647$ & $1,066,319$ & 0.67 & 0.33 \\
\hline
\end{tabular}

* (Unit: Million KRW) / total value added (Table 4) = capital (Table 5) + compensation of employees (Table 5) 
whether productivity gain of individual sectors affected other sectors via price change in intermediary goods or in final consumption.

The Table 4 shows that in 2000, IT hardware industry created a benefit of $76,406,650$ million KRW on the whole economy, of which 13,804,500 million KRW was an effect on other industries (Table 8). The difference of 62,602,150 million KRW was interpreted to consist of benefit in final consumption. In 2005, IT hardware industry created a benefit of $280,926,591$ million KRW on the whole economy, of which $184,884,923$ million KRW.

In 2000, IT service industry created a benefit of $-2,604,164$ million KRW on the whole economy, but lowered costs of other industries by $36,524,457$ million. A net loss of $-39,128,621$ million KRW was transferred to final consumption. In 2005, total economic benefit was $-5,799,013$ million KRW and cost lowering effect was found to be $-1,699,738$ million, resulting in net effect of $-4,099,275$ million KRW on final consumption.

Table 8 shows how IT hardware and IT service industries each affected other industries. In 2000, IT hardware brought about 13,804,500 million KRW of cost reduction to other industries, with $21.53 \%$ for sector $13,2.87 \%$ for sector 14 and $1.39 \%$ for sector 8 . Sector 29 is exempted as it consists of IT hardware. In 200 there was 96,041,668 million KRW of cost reduction, which is a great reduction from 2000. Sectors most affected were sector 13 at $31.15 \%$, IT service (sector 30 ) at $6.25 \%$, and sector 14 at $2.39 \%$. This shows that the effects of IT hardware on IT service has increased with time.

IT service industry reduced costs of other industries by $36,524,457$ million KRW in 2000 . The sectors most affected are sector 8 at 20.23\%, sector 10 at $14.53 \%$, and sector 22 at $11.872 \%$. On the other hand, in 2005 , IT service increased costs of all sectors cumulating in total increase of $1,699,738$ million KRW. Costs of IT service (sector 30 ) rose by $21.25 \%$, sector 22 by $14.46 \%$, sector 23 by $11.34 \%$, sector 26 by $5.06 \%$ (Tables 8,9).

Compared to IT hardware industry, IT service industry was found to affect all sectors more evenly, and especially on knowledge services as time went by. The correlation between IT hardware industry and IT service industry also seems to have grown closer.

Table 10 presents the variance result of the analysis on the productivity spillover effect of each IT industry and on the bias of the effect on particular industries. In regard to the effect on the secondary industry in 2000, the effect of IT hardware accounted for $96.9 \%$, down to $90.8 \%$ in 2005 . The change led to a rise in the effect on the tertiary industry in 2005. In IT service, more clear changes were found. In other words, in 2000, its effect on the secondary industry reached $60.7 \%$, but in 2005 the effect on the secondary industry sharply fell to $29.3 \%$ and the effect on the tertiary industry soared to $70.5 \%$. In addition, the effect of IT service on the primary industry greatly increased from $0.07 \%$ in 2000 to $0.22 \%$ in 2005 . However, the productivity spillover effect of IT service showed negative (-) value overall in 2005. Although the issue is required to be analyzed in another study, it is speculated that from early 2000 to mid-2000 investments in IT service had considerably increased, but since then they had failed to lead to the effect of direct cost reduction. The issue needs to be analyzed in the future research. It is impossible to deny that the IT industry now influences the tertiary industry, rather than the secondary industry, and give the effect on overall economy.

\section{Conclusion}

Both IT hardware and IT service influenced the Korean economy more greatly in 2005, than in 2000. In the case of IT hardware, its TFP soared from 2.313 in 2000 to 3.906 in 2005, which was the largest among the TFPs of all industries. The benefit that affects the overall economy increased from KRW 76,406,650 million to KRW $286,391,295$, up almost four fold. TFP of IT service was 0.99 both in 2000 and in 2005, but the benefit decreased more than two fold from KRW -93,463 million to KRW -190,004million. That was attributable to increases in prices of all investment elements. The investment also increased more than twice from KRW 2,604,164 million in 2000 to KRW 5,799,013 million in 2005.

In the analysis on productivity spillover effect, what needs to be focused on is that the spillover effect of IT hardware on overall industries was found more evenly in 2005 and that the tertiary industry has become more important. IT service greatly influenced the secondary industry in 2000 , whereas its productivity spillover effect on the tertiary industry sharply increased 
Table 8. IT Service and Hardware TFP spillover (2000)

\begin{tabular}{|c|c|c|c|c|c|c|c|c|c|}
\hline & & & & & & & \multicolumn{3}{|c|}{ hardware } \\
\hline & $\mathbf{R}$ & Rank & cost & Rank & industry impact & Rank & hardware & rate & Rank \\
\hline 1 & $-3,183,305$ & 19 & $-2,593,297$ & 26 & $-590,007$ & 7 & -90 & $0.00 \%$ & 27 \\
\hline 2 & $-14,052,590$ & 29 & 285,403 & 13 & $-14,337,993$ & 28 & -764 & $-0.01 \%$ & 29 \\
\hline 3 & $-3,866,248$ & 22 & $14,046,618$ & 3 & $-17,912,866$ & 29 & 1,569 & $0.01 \%$ & 23 \\
\hline 4 & $-2,392,916$ & 14 & $8,236,795$ & 6 & $-10,629,711$ & 25 & 1,100 & $0.01 \%$ & 25 \\
\hline 5 & $-3,048,100$ & 18 & $-1,407,102$ & 20 & $-1,640,998$ & 13 & 1,216 & $0.01 \%$ & 24 \\
\hline 6 & $-845,787$ & 10 & $-485,880$ & 16 & $-359,907$ & 6 & 10,751 & $0.08 \%$ & 17 \\
\hline 7 & $-19,892,766$ & 30 & $-11,669,397$ & 30 & $-8,223,369$ & 22 & 2,323 & $0.02 \%$ & 22 \\
\hline 8 & $-9,120,182$ & 28 & $4,432,587$ & 7 & $-13,552,768$ & 27 & 6,235 & $0.05 \%$ & 19 \\
\hline 9 & $-2,310,506$ & 13 & 32,462 & 14 & $-2,342,968$ & 15 & 927 & $0.01 \%$ & 26 \\
\hline 10 & $-8,128,987$ & 26 & $1,681,260$ & 10 & $-9,810,247$ & 23 & 4,970 & $0.04 \%$ & 20 \\
\hline 11 & $-2,744,739$ & 16 & $-1,661,941$ & 22 & $-1,082,798$ & 11 & -369 & $0.00 \%$ & 28 \\
\hline 12 & $-3,234,350$ & 20 & $10,004,633$ & 5 & $-13,238,983$ & 26 & 49,389 & $0.36 \%$ & 9 \\
\hline 13 & 156,971 & 4 & $10,764,407$ & 4 & $-10,607,436$ & 24 & $2,971,701$ & $21.53 \%$ & 2 \\
\hline 14 & $-817,461$ & 9 & $3,179,499$ & 8 & $-3,996,959$ & 19 & 395,954 & $2.87 \%$ & 3 \\
\hline 15 & $-2,947,919$ & 17 & $-457,495$ & 15 & $-2,490,424$ & 16 & 102,368 & $0.74 \%$ & 6 \\
\hline 16 & $-468,750$ & 6 & $1,120,636$ & 12 & $-1,589,387$ & 12 & 36,104 & $0.26 \%$ & 11 \\
\hline 17 & $-4,717,768$ & 25 & $-2,567,200$ & 25 & $-2,150,568$ & 14 & 10,645 & $0.08 \%$ & 18 \\
\hline 18 & $-2,686,258$ & 15 & $336,386,934$ & 1 & $-339,073,192$ & 30 & 191,367 & $1.39 \%$ & 4 \\
\hline 19 & $-3,785,103$ & 21 & $-2,778,637$ & 27 & $-1,006,466$ & 8 & 31,952 & $0.23 \%$ & 13 \\
\hline 20 & $-1,386,580$ & 11 & $-3,624,622$ & 29 & $2,238,042$ & 3 & 4,126 & $0.03 \%$ & 21 \\
\hline 21 & $-4,557,131$ & 24 & $-688,701$ & 17 & $-3,868,431$ & 18 & $-25,180$ & $-0.18 \%$ & 30 \\
\hline 22 & $-699,142$ & 7 & $2,584,395$ & 9 & $-3,283,537$ & 17 & 42,251 & $0.31 \%$ & 10 \\
\hline 23 & $-8,936,654$ & 27 & $-1,831,665$ & 23 & $-7,104,989$ & 20 & 31,361 & $0.23 \%$ & 15 \\
\hline 24 & $437,121,725$ & 1 & $-1,248,289$ & 19 & $438,370,014$ & 1 & 74,735 & $0.54 \%$ & 7 \\
\hline 25 & 0 & 5 & $-1,997,047$ & 24 & $1,997,047$ & 4 & 32,192 & $0.23 \%$ & 12 \\
\hline 26 & $-770,030$ & 8 & $-1,627,122$ & 21 & 857,092 & 5 & 27,585 & $0.20 \%$ & 16 \\
\hline 27 & $-1,911,309$ & 12 & $-878,742$ & 18 & $-1,032,567$ & 10 & 54,182 & $0.39 \%$ & 8 \\
\hline 28 & $-4,050,309$ & 23 & $-3,018,483$ & 28 & $-1,031,826$ & 9 & 31,888 & $0.23 \%$ & 14 \\
\hline 29 & $13,804,500$ & 3 & $21,504,599$ & 2 & $-7,700,100$ & 21 & $9,587,993$ & $69.46 \%$ & 1 \\
\hline 30 & $36,524,457$ & 2 & $1,328,155$ & 11 & $35,196,301$ & 2 & 126,019 & $0.91 \%$ & 5 \\
\hline
\end{tabular}

* (Unit: Million KRW) 
Table 9. IT Service and Hardware TFP spillover (2005)

\begin{tabular}{|c|c|c|c|c|c|c|c|c|c|c|c|c|}
\hline & & & & & & & \multicolumn{3}{|c|}{ hardware } & \multicolumn{3}{|c|}{ Service } \\
\hline & $\mathbf{R}$ & Rank & cost & Rank & $\begin{array}{l}\text { industry } \\
\text { impact }\end{array}$ & Rank & hardware & rate & Rank & Service & rate & Rank \\
\hline 1 & $-6,573,156$ & 17 & $-5,528,450$ & 13 & $-1,044,707$ & 17 & -134 & $0.00 \%$ & 26 & -2449 & $0.14 \%$ & 28 \\
\hline 2 & $-38,779,247$ & 28 & $-375,741$ & 5 & $-38,403,506$ & 30 & -755 & $0.00 \%$ & 27 & -1289 & $0.08 \%$ & 29 \\
\hline 3 & $-9,490,279$ & 21 & $-10,782,962$ & 22 & $1,292,682$ & 14 & 5,799 & $0.01 \%$ & 22 & -15161 & $0.89 \%$ & 19 \\
\hline 4 & $-1,649,110$ & 7 & $-3,885,485$ & 9 & $2,236,375$ & 12 & 2,350 & $0.00 \%$ & 25 & -21860 & $1.29 \%$ & 17 \\
\hline 5 & $-3,115,473$ & 11 & $-2,024,091$ & 8 & $-1,091,382$ & 19 & 2,983 & $0.00 \%$ & 24 & -6963 & $0.41 \%$ & 23 \\
\hline 6 & $-2,645,607$ & 10 & $-1,084,256$ & 6 & $-1,561,351$ & 20 & 46,777 & $0.05 \%$ & 16 & -5103 & $0.30 \%$ & 25 \\
\hline 7 & $-41,221,103$ & 29 & $-30,173,952$ & 28 & $-11,047,151$ & 26 & 11,279 & $0.01 \%$ & 20 & -12541 & $0.74 \%$ & 20 \\
\hline 8 & $-32,691,107$ & 27 & $-39,486,062$ & 29 & $6,794,955$ & 5 & 18,002 & $0.02 \%$ & 19 & -50794 & $2.99 \%$ & 9 \\
\hline 9 & $-3,626,222$ & 12 & $-4,002,362$ & 10 & 376,140 & 16 & 4,899 & $0.01 \%$ & 23 & -5612 & $0.33 \%$ & 24 \\
\hline 10 & $-54,945,210$ & 30 & $-39,531,155$ & 30 & $-15,414,055$ & 28 & 20,818 & $0.02 \%$ & 18 & -21562 & $1.27 \%$ & 18 \\
\hline 11 & $-13,304,212$ & 24 & $-10,296,362$ & 21 & $-3,007,849$ & 22 & $-4,173$ & $0.00 \%$ & 28 & -9713 & $0.57 \%$ & 22 \\
\hline 12 & $-4,452,196$ & 15 & $-10,142,741$ & 20 & $5,690,545$ & 7 & 993,175 & $1.03 \%$ & 6 & -47299 & $2.78 \%$ & 12 \\
\hline 13 & $9,048,419$ & 2 & $29,866,350$ & 2 & $-20,817,931$ & 29 & $29,917,326$ & $31.15 \%$ & 2 & -29308 & $1.72 \%$ & 14 \\
\hline 14 & 74,938 & 4 & $1,127,909$ & 4 & $-1,052,971$ & 18 & $2,291,226$ & $2.39 \%$ & 4 & -11338 & $0.67 \%$ & 21 \\
\hline 15 & $-7,060,592$ & 18 & $-16,898,567$ & 26 & $9,837,975$ & 3 & $1,251,264$ & $1.30 \%$ & 5 & -27661 & $1.63 \%$ & 15 \\
\hline 16 & $-1,002,388$ & 6 & $-1,778,019$ & 7 & 775,631 & 15 & 146,779 & $0.15 \%$ & 15 & -2819 & $0.17 \%$ & 27 \\
\hline 17 & $-9,054,579$ & 20 & $-12,217,208$ & 23 & $3,162,629$ & 11 & $-29,656$ & $-0.03 \%$ & 29 & -21901 & $1.29 \%$ & 16 \\
\hline 18 & $-3,847,727$ & 13 & $-22,838,963$ & 27 & $18,991,236$ & 2 & $-468,122$ & $-0.49 \%$ & 30 & -44133 & $2.60 \%$ & 13 \\
\hline 19 & $-12,004,961$ & 23 & $-8,282,912$ & 18 & $-3,722,049$ & 23 & 238,088 & $0.25 \%$ & 12 & -76753 & $4.52 \%$ & 7 \\
\hline 20 & $-4,245,236$ & 14 & $-8,202,822$ & 17 & $3,957,586$ & 10 & 26,432 & $0.03 \%$ & 17 & -4454 & $0.26 \%$ & 26 \\
\hline 21 & $-7,652,647$ & 19 & $-15,417,492$ & 25 & $7,764,845$ & 4 & 7,262 & $0.01 \%$ & 21 & -49679 & $2.92 \%$ & 10 \\
\hline 22 & $1,025,363$ & 3 & $-5,037,299$ & 12 & $6,062,662$ & 6 & 724,691 & $0.75 \%$ & 8 & -245797 & $14.46 \%$ & 2 \\
\hline 23 & $-17,497,648$ & 25 & $-8,396,256$ & 19 & $-9,101,392$ & 25 & 154,571 & $0.16 \%$ & 13 & -192710 & $11.34 \%$ & 3 \\
\hline 24 & $-27,711,332$ & 26 & $-13,023,636$ & 24 & $-14,687,696$ & 27 & 734,474 & $0.76 \%$ & 7 & -77736 & $4.57 \%$ & 6 \\
\hline 25 & 0 & 5 & $-4,826,671$ & 11 & $4,826,671$ & 8 & 297,340 & $0.31 \%$ & 9 & -54703 & $3.22 \%$ & 8 \\
\hline 26 & $-2,536,570$ & 9 & $-7,213,845$ & 15 & $4,677,274$ & 9 & 152,550 & $0.16 \%$ & 14 & -85991 & $5.06 \%$ & 5 \\
\hline 27 & $-4,485,239$ & 16 & $-6,200,301$ & 14 & $1,715,062$ & 13 & 273,242 & $0.28 \%$ & 10 & -49636 & $2.92 \%$ & 11 \\
\hline 28 & $-9,738,865$ & 22 & $-7,867,024$ & 16 & $-1,871,841$ & 21 & 252,648 & $0.26 \%$ & 11 & 0 & $0.00 \%$ & 30 \\
\hline 29 & $96,041,668$ & 1 & $45,459,535$ & 1 & $50,582,133$ & 1 & $52,969,365$ & $55.15 \%$ & 1 & -163520 & $9.62 \%$ & 4 \\
\hline 30 & $-1,699,738$ & 8 & $4,220,784$ & 3 & $-5,920,523$ & 24 & $6,001,167$ & $6.25 \%$ & 3 & -361252 & $21.25 \%$ & 1 \\
\hline
\end{tabular}

* (Unit: Million KRW) 
Table 10. Summary of IT productivity spillover effects on industries

\begin{tabular}{|c|c|c|c|c|}
\hline 2000 & hardware & rate & Service & rate \\
\hline Primary industries & -854 & $-0.01 \%$ & 24,891 & $0.07 \%$ \\
\hline Secondary industries & $13,374,243$ & $96.9 \%$ & $22,164,355$ & $60.7 \%$ \\
\hline Tertiary industries & 431,111 & $3.1 \%$ & $14,335,211$ & $39.2 \%$ \\
\hline Total & $13,804,500$ & $100 \%$ & $36,524,457$ & $100 \%$ \\
\hline Variance & \multicolumn{2}{|c|}{0.0171} & \multicolumn{2}{|c|}{0.0025} \\
\hline \multicolumn{5}{|c|}{2005} \\
\hline Primary industries & -889 & $0.00 \%$ & $-3,738$ & $0.22 \%$ \\
\hline Secondary industries & $87,180,091$ & $90.8 \%$ & $-497,288$ & $29.3 \%$ \\
\hline Tertiary industries & $8,862,465$ & $9.2 \%$ & $-1,198,711$ & $70.5 \%$ \\
\hline Total & $96,041,667$ & $100 \%$ & $-1,699,737$ & $100 \%$ \\
\hline Variance & \multicolumn{2}{|c|}{0.0129} & \multicolumn{2}{|c|}{0.0023} \\
\hline
\end{tabular}

*IT Hardware included in Secondary industries, IT Service included in Tertiary industries

in 2005 and the effect on the secondary industry considerably fell.

The study results bring about the following suggestions: First, the productivity of The IT industry positively influenced the Korean economy. In particular, in the case of IT hardware, its economic benefit caused by the productivity was the highest of the benefits of all industries. Secondly, the spillover effect of The IT industry expanded from the secondary industry to the tertiary industry. In the case of IT service, its effect on the tertiary industry was found clearly in 2005 , compared to 2000. The importance of the spillover effect of IT hardware on the tertiary industry was changed largely. Thirdly, with the lapse of time, the IT industry evenly influenced the overall industries, rather than particular industries. The variance of each industrial weight of the productivity spillover effect decreased in 2005, compared to 2000.

This study has the following limitations: In the case of IT service, the investment increased twice in 2005, compared to 2000. According to 2005 analysis, it negatively influenced economic benefit and cost reduction in each industry. Nevertheless, it is hard to define that IT service negatively affects the economy. The reason for such results is that this study analyzed the 2000 and 2005 spillover effect of TFP on each industry with the use of linked input-output tables, and the analysis results were analyzed on the basis of the prices of investment elements. The effects made with the lapse of time were not taken into account, and price changes were analyzed at a given point. In addition, the management and application of IT service were not taken into consideration in terms of qualitative aspect.

In regard to the influence of certain investment elements, it is possible to analyze the influential results properly after some time. In particular, in the case of IT service, its outcomes appear after IT hardware capital is mature enough (Shin 2013). According to this study, IT hardware brought about its outcomes differently, depending on the extent of direct investment elements. However, in the case of IT service, its investment industry changes from the secondary industry to the tertiary industry, and the productivity is found different depending on the extent of hardware infrastructure and IT application level of each industry. Therefore, it is hard to expect the productivity spillover effect of IT service immediately.

Given that, the future study needs to use production function to analyze the influence with the lapse of time, and look into other managerial aspects than economic approach in order for productivity and efficient use of IT service.

\section{Acknowledgement}

This work was supported by the Ministry of Education of the Republic of Korea and the National Research Foundation of Korea (NRF2015S1A5B5A07042634) 


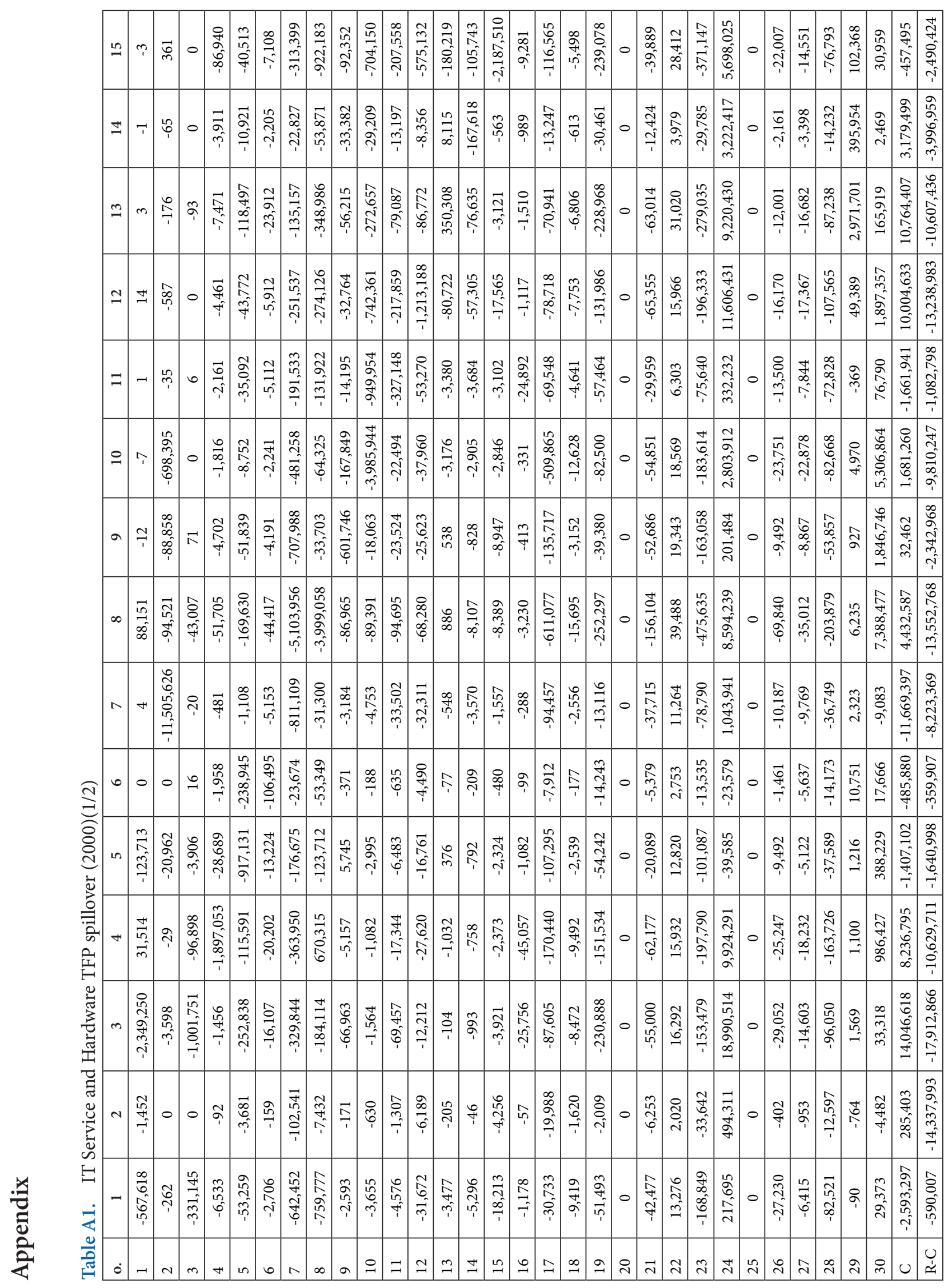




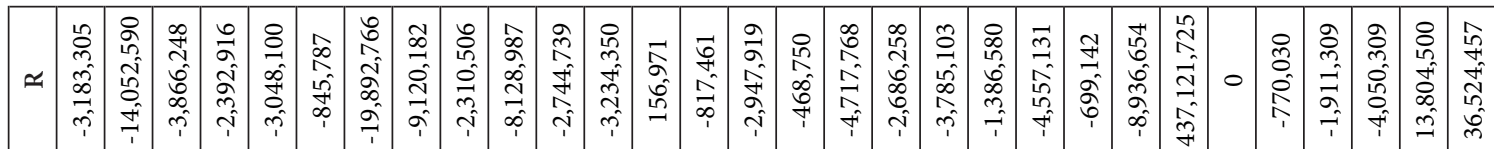

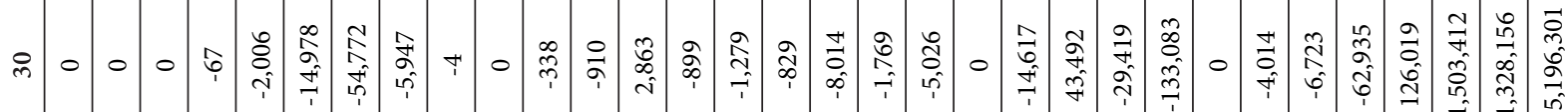

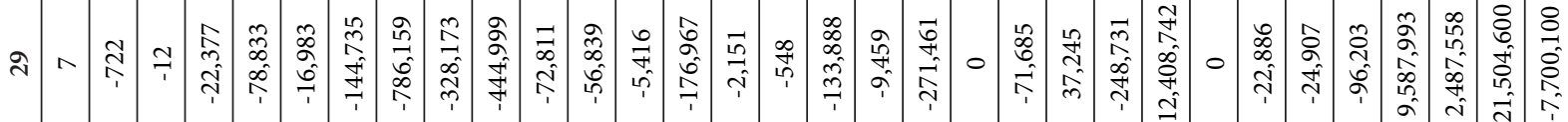

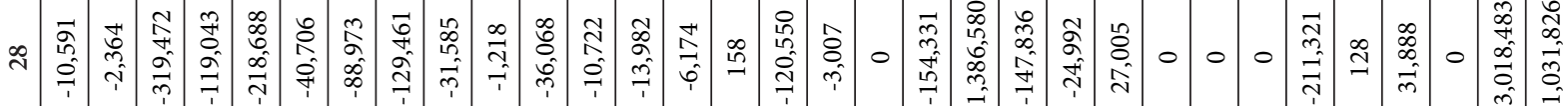

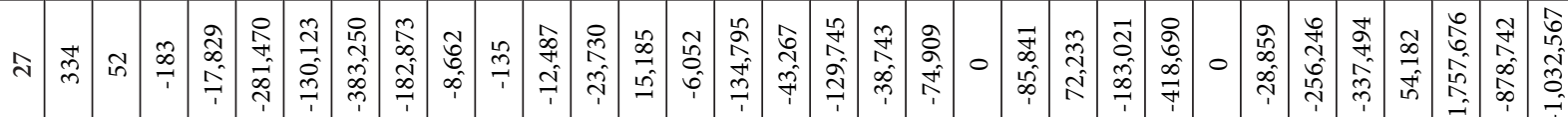

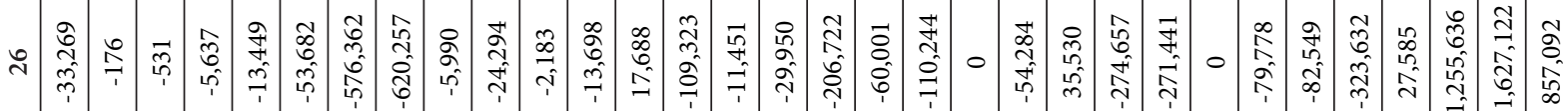

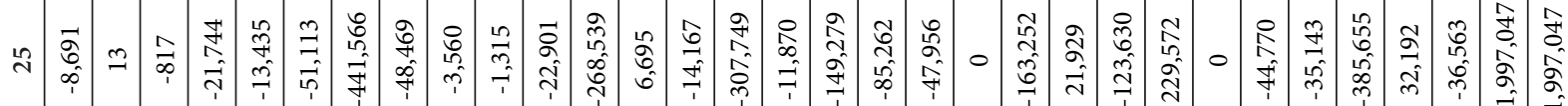

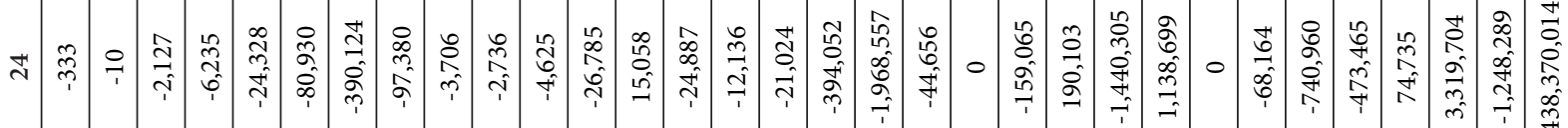

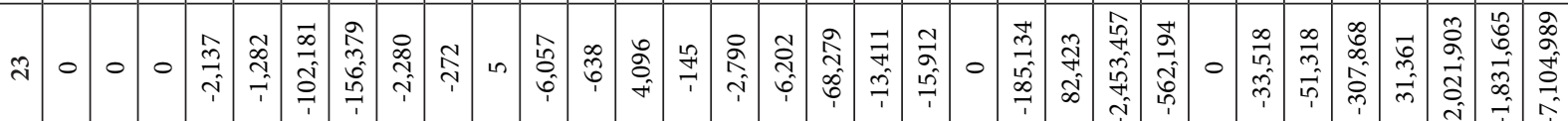

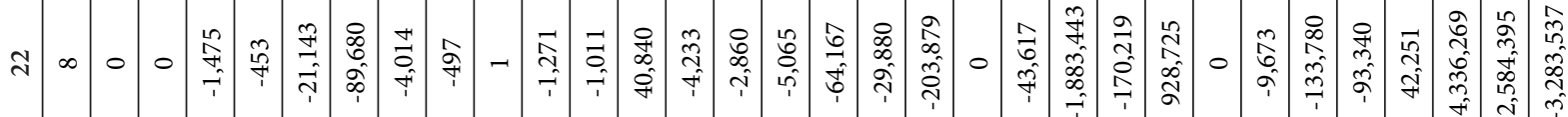

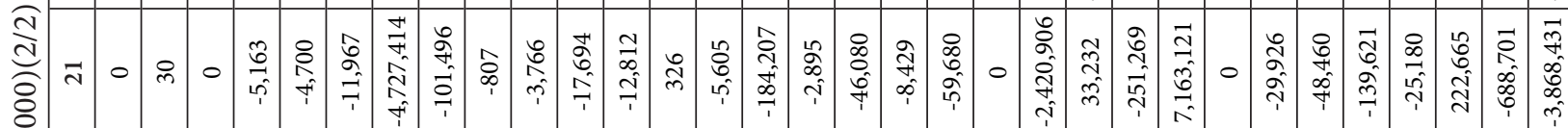

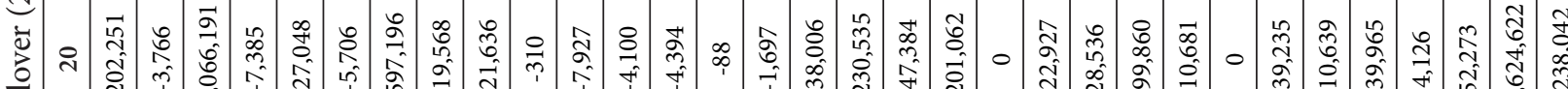
है

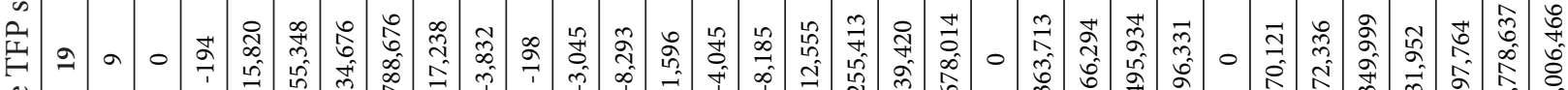

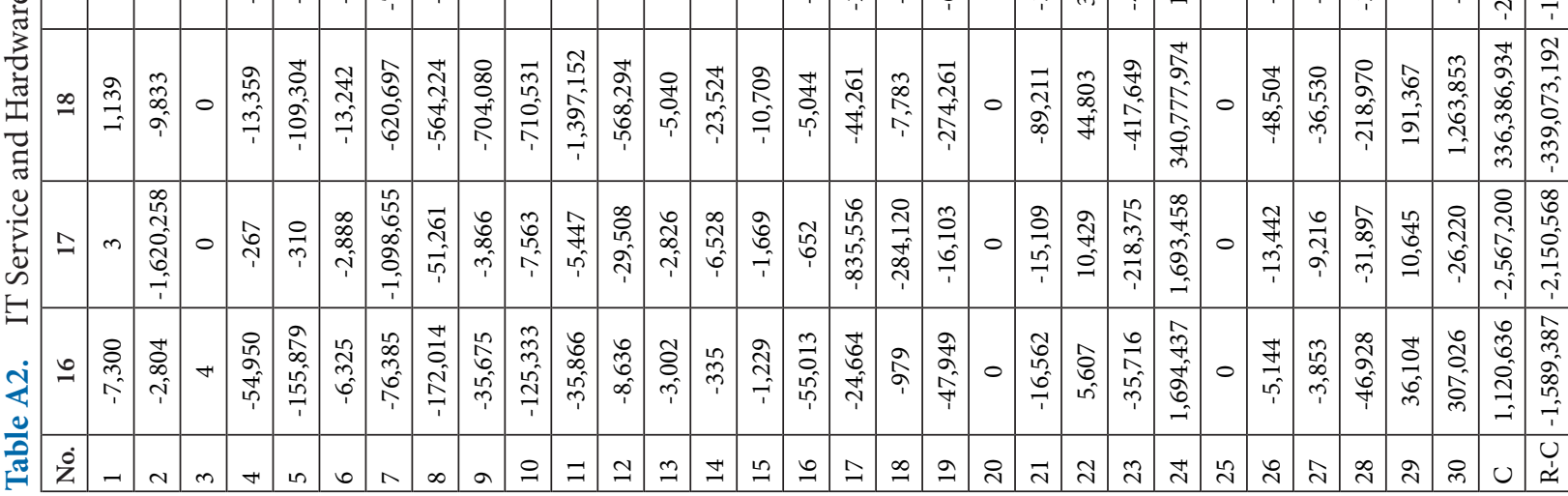




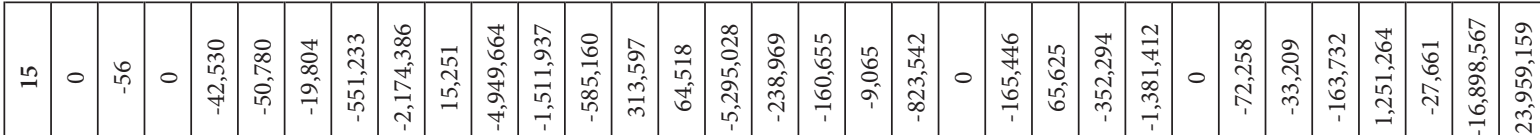

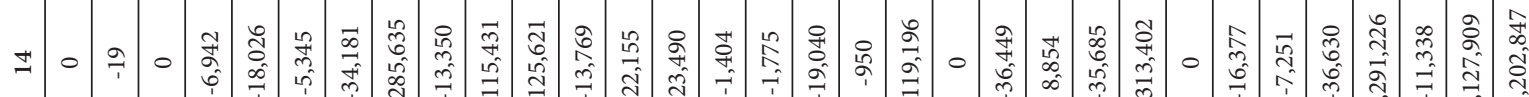

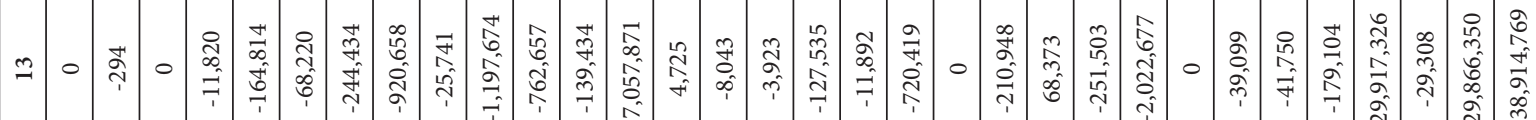

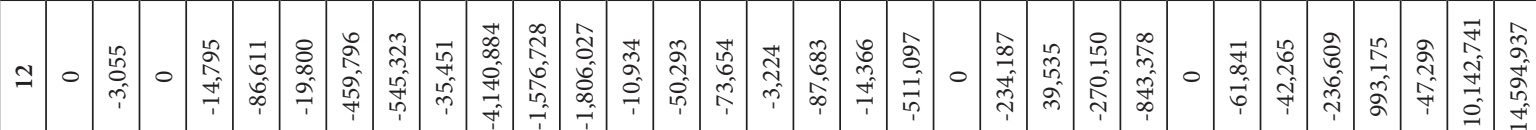

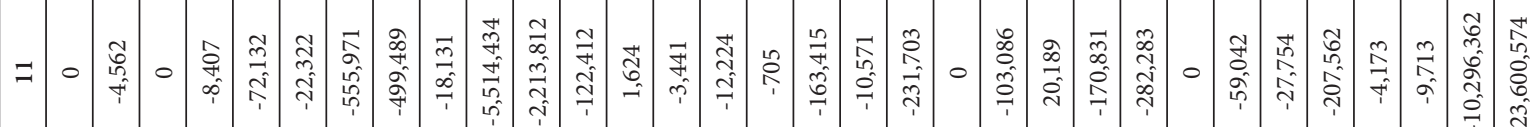

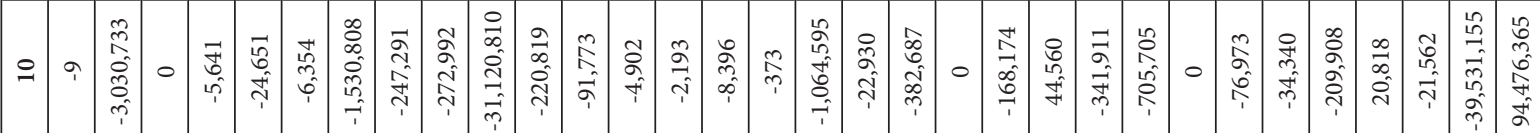

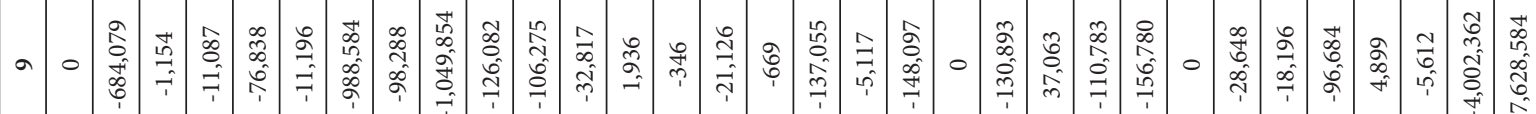

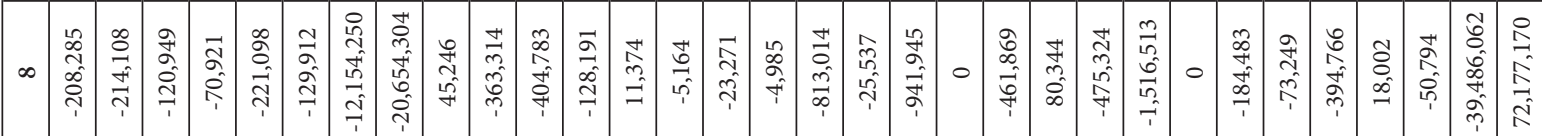

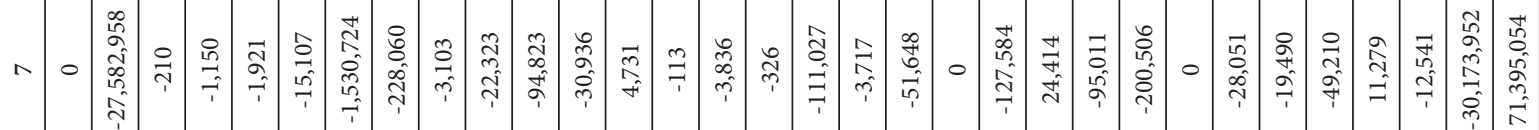

\begin{tabular}{|c|c|c|c|c|c|c|c|c|c|c|c|c|c|c|c|c|c|c|c|c|c|c|c|c|c|c|c|c|c|c|c|}
\hline & | & 0 & 0 & 0 & $\mid \begin{array}{l}2 \\
2 \\
d\end{array}$ & 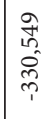 & $\begin{array}{c}0 \\
0 \\
\infty \\
\hat{\infty} \\
\hat{m}\end{array}$ & 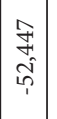 & $\begin{array}{l}\tilde{n} \\
\hat{0} \\
\hat{0}\end{array}$ & $\overrightarrow{\mathcal{F}}$ & $\overrightarrow{\mathbb{N}}$ & 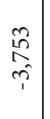 & $\begin{array}{l}\widehat{\hat{6}} \\
\hat{i}\end{array}$ & $\begin{array}{l}0 \\
\text { pl }\end{array}$ & $\stackrel{\infty}{i}$ & ה్ & $\stackrel{n}{10}$ & & ల్లి & 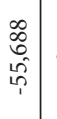 & $0 \mid \begin{array}{l}0 \\
0\end{array}$ & 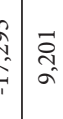 & 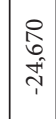 & $\left|\begin{array}{l}0 \\
0 \\
0 \\
1\end{array}\right|$ & 0 & 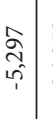 & 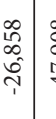 & & $\stackrel{8}{\stackrel{8}{5}}$ & & \\
\hline & 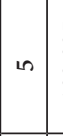 & 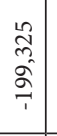 & $\mid \begin{array}{l}0 \\
\stackrel{1}{1} \\
\stackrel{+}{+}\end{array}$ & $\begin{array}{l}\vec{N} \\
\stackrel{2}{=}\end{array}$ & $\mid$\begin{tabular}{|l}
$\overrightarrow{\hat{N}}$ \\
$\hat{\imath}$ \\
$\hat{\imath}$
\end{tabular} & 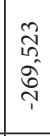 & $\begin{array}{l}\hat{\mathbb{N}} \\
\hat{+} \\
\vec{r}\end{array}$ & 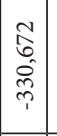 & $\begin{array}{l}\hat{2} \\
\hat{\alpha} \\
0 \hat{0} \\
\hat{1}\end{array}$ & $\begin{array}{l}0 \\
0 \\
0 \\
n \\
0\end{array}$ & 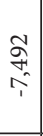 & 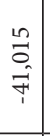 & 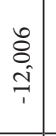 & $\begin{array}{c}8 \\
\vec{v} \\
\hat{v}\end{array}$ & $\stackrel{\vec{m}}{.}$ & 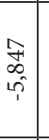 & 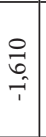 & & 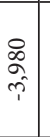 & $\begin{array}{c}0 \\
0 \\
0 \\
\vec{a} \\
\vec{a}\end{array}$ & 0 & 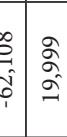 & $\begin{array}{l}0 \\
0 \\
0 \\
0 \\
0 \\
1\end{array}$ & $\mid \begin{array}{l}\hat{a} \\
\hat{\alpha} \\
\hat{\jmath} \\
7\end{array}$ & 0 & $\overrightarrow{0}$ & 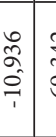 & & $\begin{array}{l}0 \\
0 \\
0 \\
0\end{array}$ & & \\
\hline & + & 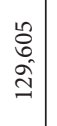 & $\mid \begin{array}{c}\hat{\grave{2}} \\
\overrightarrow{+}\end{array}$ & 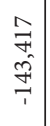 & 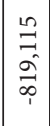 & $\begin{array}{l}\vec{\partial} \\
\hat{\sigma} \\
\hat{\sigma} \\
\hat{1}\end{array}$ & 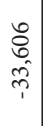 & 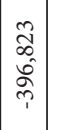 & 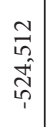 & 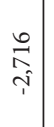 & $\begin{array}{l}\vec{a} \\
\vec{i} \\
i\end{array}$ & 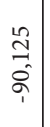 & $\underset{\vec{m}}{\vec{t}}$ & $\begin{array}{c}\overrightarrow{\widetilde{\sigma}} \\
\stackrel{\mathrm{m}}{ }\end{array}$ & $\vec{\sigma}$ & $\begin{array}{l}\vec{m} \\
\vec{m}\end{array}$ & 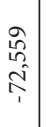 & & $\begin{array}{l}\infty \\
0 \\
0 \\
0 \\
0\end{array}$ & 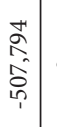 & $0 \mid \begin{array}{l}2 \\
0 \\
0 \\
5 \\
7\end{array}$ & 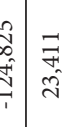 & $\begin{array}{l}\hat{n} \\
0 \\
0 \\
0 \\
\frac{0}{1}\end{array}$ & $\mid \begin{array}{l}2 \\
\hat{2} \\
\overrightarrow{0} \\
7\end{array}$ & 0 & 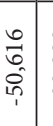 & 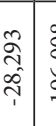 & & $\begin{array}{l}0 \\
0 \\
\infty \\
\vec{T} \\
\end{array}$ & & \\
\hline & $m$ & $\begin{array}{l}\tilde{z} \\
\alpha \\
0 \\
\infty \\
\infty \\
+ \\
f\end{array}$ & 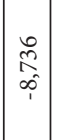 & 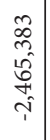 & 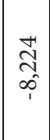 & 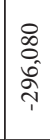 & 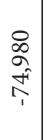 & 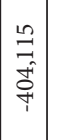 & $\begin{array}{l}\infty \\
0 \\
0 \\
m \\
m\end{array}$ & $\mid \begin{array}{l}1 \\
0 \\
0 \\
b_{f}^{2} \\
f\end{array}$ & $\begin{array}{l}0 \\
\stackrel{0}{2} \\
\stackrel{2}{2} \\
r\end{array}$ & 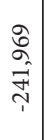 & 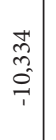 & $\begin{array}{c}0 \\
0 \\
0 \\
i n\end{array}$ & 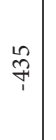 & 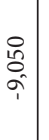 & 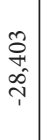 & & $\begin{array}{l}m \\
\vec{Z} \\
= \\
=\end{array}$ & 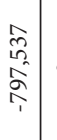 & $0 \mid$\begin{tabular}{l|l}
0 \\
0 \\
0 \\
0
\end{tabular} & 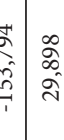 & 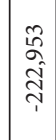 & 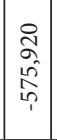 & 。 & 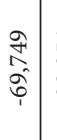 & 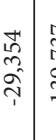 & & $\begin{array}{l}\overrightarrow{5} \\
\stackrel{5}{7}\end{array}$ & & \\
\hline & $\sim$ & $\begin{array}{l}\mathbb{Z} \\
\underset{\exists}{*}\end{array}$ & 0 & 0 & 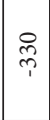 & 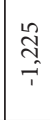 & $\stackrel{\vec{r}}{\vec{r}}$ & $\mid \begin{array}{c}\infty \\
2 \\
0 \\
\infty \\
-1 \\
-1\end{array}$ & 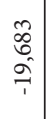 & $\stackrel{\hat{m}}{\rightarrow}$ & $\begin{array}{l}m \\
\vec{G} \\
\overrightarrow{1}\end{array}$ & 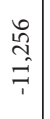 & \begin{tabular}{l}
0 \\
0 \\
0 \\
\multicolumn{1}{|c|}{}
\end{tabular} & $\Xi$ & $\hat{\imath}$ & $\begin{array}{c}\wedge \\
\vec{\sigma}\end{array}$ & $\underset{T}{T}$ & 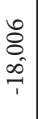 & 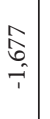 & 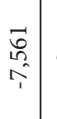 & 0 & 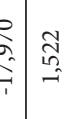 & $\begin{array}{l}\widehat{\widehat{\infty}} \\
\widehat{\infty} \\
\stackrel{1}{1}\end{array}$ & 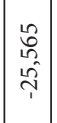 & 0 & $\stackrel{\text { త్ }}{్}$ & $\begin{array}{l}\hat{O} \\
\hat{0} \\
\hat{i}\end{array}$ & & 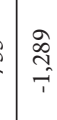 & & \\
\hline & -1 & $\begin{array}{l}0 \\
0 \\
0 \\
0 \\
\text { in }\end{array}$ & $\mid \begin{array}{l}\tilde{F} \\
\tilde{F}\end{array}$ & $\begin{array}{l}\vec{a} \\
\stackrel{0}{0} \\
\stackrel{0}{1} \\
\rightarrow\end{array}$ & $\mid \begin{array}{c}\tilde{z} \\
\tilde{0} \\
\hat{\sim} \\
+\end{array}$ & $\begin{array}{c}0 \\
0 \\
0 \\
0 \\
0 \\
10 \\
1\end{array}$ & 芯 & 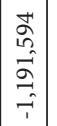 & $\begin{array}{c}n \\
\hat{A} \\
\infty \\
0 \\
0 \\
-1 \\
-1\end{array}$ & $\hat{\alpha}_{i}$ & $\begin{array}{l}0 \\
0 \\
0 \\
0 \\
0 \\
1\end{array}$ & $\begin{array}{l}\hat{\alpha} \\
\hat{t} \\
\bar{t}\end{array}$ & 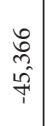 & 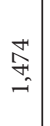 & $\begin{array}{l}\vec{H} \\
\stackrel{0}{0} \\
\hat{r}\end{array}$ & 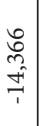 & $\underset{\rightarrow}{\vec{F}}$ & 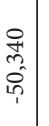 & 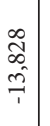 & 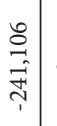 & $0 \mid \begin{array}{ll}0 \\
0 \\
0\end{array}$ & 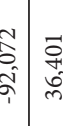 & $\mid \begin{array}{l}\hat{0} \\
\hat{0} \\
\hat{\tilde{N}}\end{array}$ & $\left|\begin{array}{c}1 \\
\hat{0} \\
0 \\
\hat{a}\end{array}\right|$ & 0 & $\begin{array}{l}\text { of } \\
0 \\
0 \\
0 \\
1\end{array}$ & 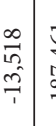 & & 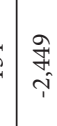 & 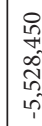 & \\
\hline & in & - & $\mathrm{a}$ & $m$ & $\theta$ & in & 0 & $\wedge$ & $\infty$ & $a$ & 인 & $\exists$ & $\approx$ & $\cong$ & \pm & $\stackrel{2}{2}$ & 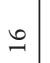 & $\triangle$ & $\stackrel{\infty}{\sim}$ & 2 & i) & $\vec{\pi} \approx$ & $\tilde{\pi}$ & $\underset{\sim}{*}$ & $\stackrel{\sim}{\sim}$ & 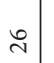 & $\hat{\mathrm{A}}$ & $\infty$ & i & u & \\
\hline
\end{tabular}




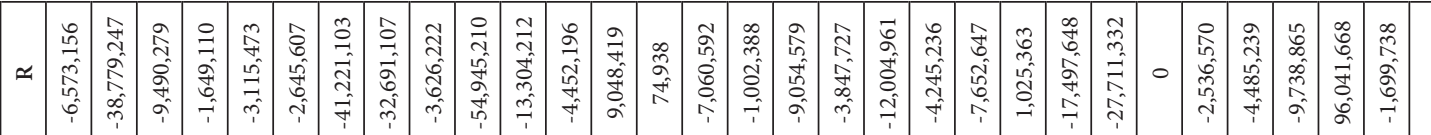

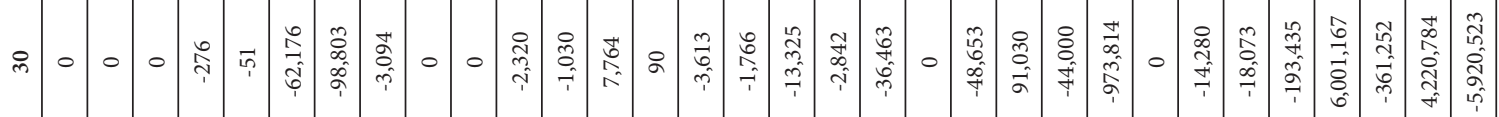

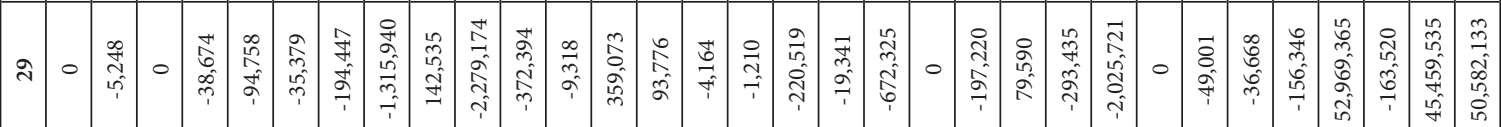

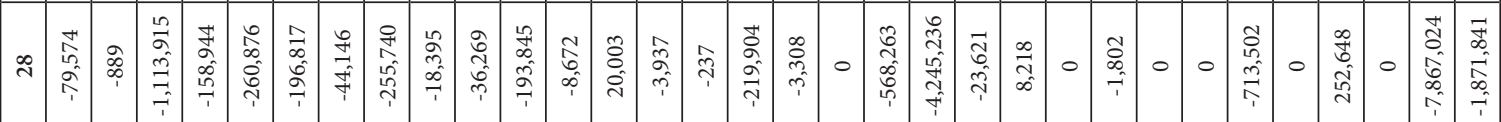

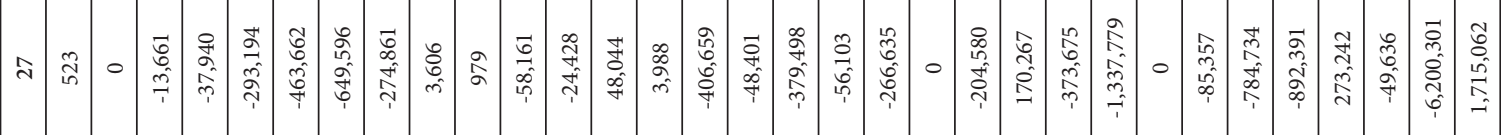

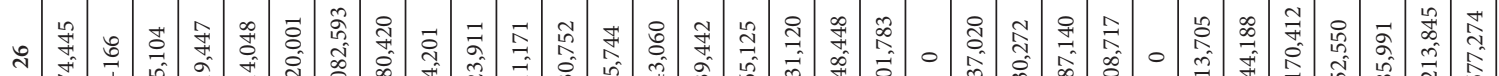

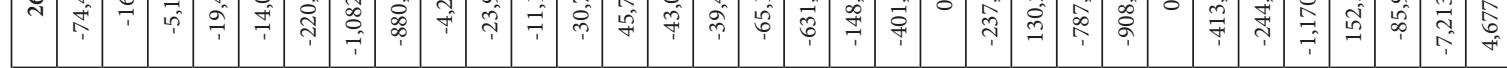

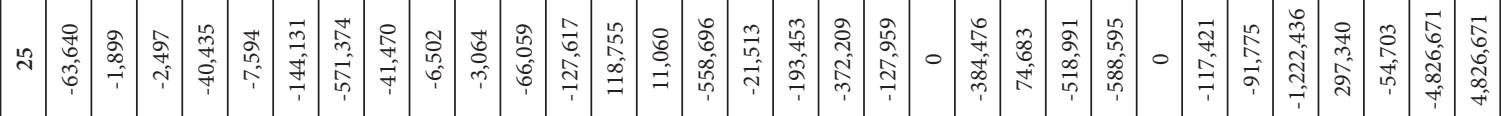

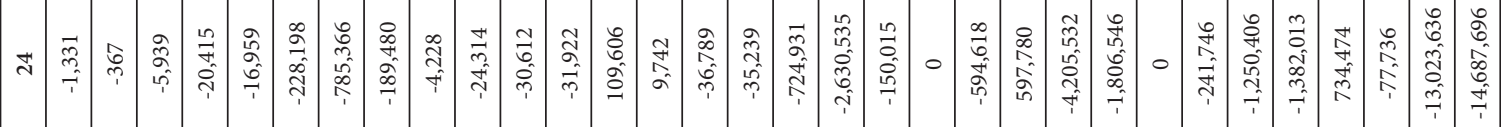

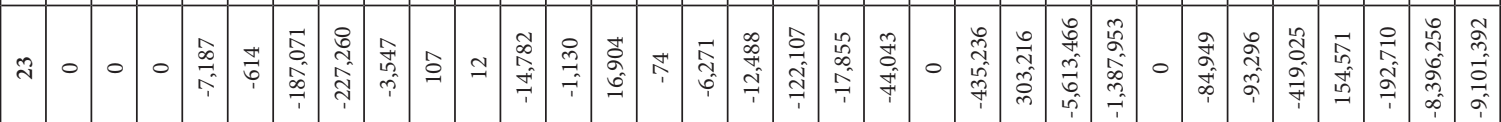

\begin{tabular}{|c|c|c|c|c|c|c|c|c|c|c|c|c|c|c|c|c|c|c|c|c|c|c|c|c|c|c|c|c|c|c|c|}
\hline & & & & 0 & ठू. & के & & & $\begin{array}{l}m \\
0 \\
\tilde{r}^{n}\end{array}$ & & & ב & q & & & 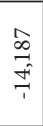 & 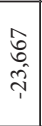 & 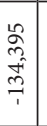 & $\begin{array}{l}\hat{a} \\
\text { ô. } \\
0\end{array}$ & है. & & 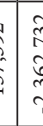 & & 语 & 0 & 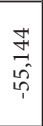 & 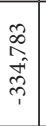 & & $\begin{array}{l}\vec{a} \\
\stackrel{d}{d} \\
\end{array}$ & 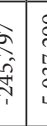 & \\
\hline & & & & 0 & $\begin{array}{l}7 \\
7 \\
\text { ? }\end{array}$ & $\begin{array}{l}0 \\
\text { in } \\
9\end{array}$ & & & $\begin{array}{l}\vec{y} \\
\text { à } \\
\text { ते }\end{array}$ & & m. & tro & 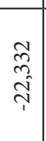 & ఫ్ & 菊 & 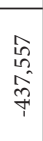 & $\frac{2}{5}$ & $\begin{array}{c}\hat{a} \\
0 \\
0 \\
0\end{array}$ & 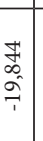 & 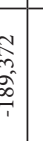 & & $=$ & & & o & $\begin{array}{l}\infty \\
0 \\
0 \\
+0\end{array}$ & 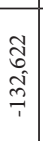 & & స్త్ర & 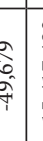 & \\
\hline & & & & $\begin{array}{l}0 \\
0 \\
0 \\
0+1 \\
0\end{array}$ & $\begin{array}{l}8 \\
0 \\
\text { t? }\end{array}$ & \begin{tabular}{l}
$f$ \\
\multirow{2}{*}{} \\
के
\end{tabular} & $\infty$ & & $\begin{array}{l}\text { w } \\
\text { ? } \\
\text { ch }\end{array}$ & & ふু & 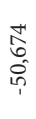 & స్లి & g & $\mathbb{1}$ & $\begin{array}{l}\text { 呆 } \\
\text { i }\end{array}$ & $\begin{array}{l}2 \\
\infty \\
\hat{0} \\
1 \\
1\end{array}$ & 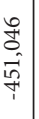 & $\begin{array}{c}\infty \\
0 \\
0 \\
0 \\
c\end{array}$ & స్ & & $\bar{z}$ & & $0_{0}^{\infty}$ & 0 & 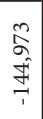 & $\begin{array}{l}0 \\
0 \\
\curvearrowright \\
\widetilde{\jmath}\end{array}$ & กิ & 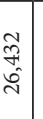 & fut & \\
\hline & & & 0 & 声 & 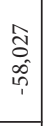 & 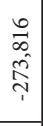 & ুু & & $\begin{array}{l}\bar{F} \\
0 \\
\end{array}$ & 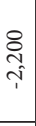 & $\infty$ & g్ & $\begin{array}{l}\infty \\
\infty \\
-7 \\
7\end{array}$ & $\overrightarrow{\mathrm{B}}$ & 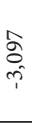 & 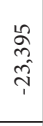 & 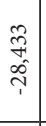 & 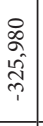 & 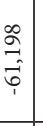 & 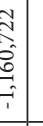 & & 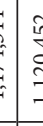 & & & o & 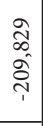 & 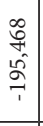 & ț & 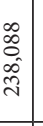 & గొ & \\
\hline & & & & 0 & $\begin{array}{c}\text { Dి } \\
\infty \\
\infty \\
\infty\end{array}$ & 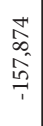 & م્ & సิ & $\begin{array}{l}\overrightarrow{0} \\
\text { م. }\end{array}$ & $\therefore$ & $\stackrel{\infty}{\stackrel{\infty}{\Sigma}}$ & $\begin{array}{l}\overrightarrow{0} \\
\text { hn } \\
1\end{array}$ & $\begin{array}{l}\vec{b} \\
0 \\
0 \\
\vec{b} \\
\overrightarrow{-}\end{array}$ & શ̊ & $\begin{array}{l}\infty \\
\infty \\
i n\end{array}$ & $\begin{array}{l}\hat{n} \\
\hat{n} \\
0 \\
0\end{array}$ & $\begin{array}{l}\hat{N} \\
\hat{f}^{2}\end{array}$ & 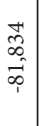 & 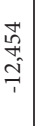 & $\begin{array}{l}\infty \\
\infty \\
\text { s. } \\
\text { fet }\end{array}$ & & 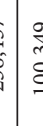 & & $\mid \begin{array}{l}\infty \\
\infty \\
0 \\
0 \\
0 \\
0\end{array}$ & o & 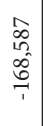 & $\begin{array}{l}\overrightarrow{8} \\
\hat{f}\end{array}$ & 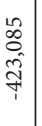 & 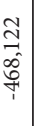 & 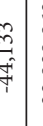 & \\
\hline & & & & 。 & $\begin{array}{l}\vec{F} \\
\vec{c}\end{array}$ & 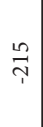 & 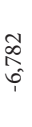 & & $\begin{array}{l}\text { f } \\
\text { t }\end{array}$ & : & 㰸 & बे & $\mid \begin{array}{l}n \\
n \\
0 \\
0\end{array}$ & $\overrightarrow{0}$ & in & $\vec{m}$ & $\mid \overrightarrow{\vec{o}}$ & 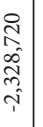 & 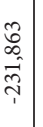 & $\begin{array}{l}\text { : } \\
\text { th } \\
h^{2}\end{array}$ & & $\frac{\alpha}{7}$ & & & o & $\begin{array}{l}\text { Fे } \\
\text { ते }\end{array}$ & 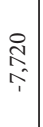 & 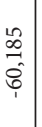 & 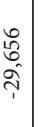 & t. & \\
\hline & & & 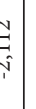 & 7 & $\begin{array}{l}2 \\
2 \\
2 \\
= \\
7\end{array}$ & $\mid \begin{array}{c}\hat{m} \\
0 \\
0 \\
-1 \\
1\end{array}$ & $\begin{array}{l}\overrightarrow{\hat{N}} \\
\vec{?}\end{array}$ & $\stackrel{\infty}{\simeq}$ & $\begin{array}{l}\text { o } \\
0 \\
\mathbb{1} \\
\text { r. }\end{array}$ & 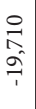 & & 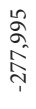 & 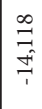 & 8 & $\infty$ & 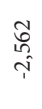 & 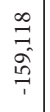 & 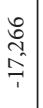 & $\underset{\overbrace{}}{\mathbb{F}}$ & 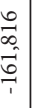 & & 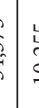 & 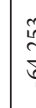 & & 0 & 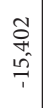 & 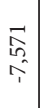 & 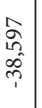 & 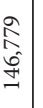 & 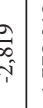 & \\
\hline & & & 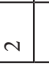 & 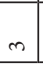 & $\vec{r}$ & in & $\checkmark$ & & $\infty$ & & & $=$ & $\approx$ & - & & 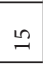 & 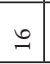 & $\triangleq$ & $\rightarrow 1$ & $\Xi$ & & 5 & & 10 & $\perp$ & $\stackrel{i}{i}$ & त & $\stackrel{\sim}{\sim}$ & ते| & m & \\
\hline
\end{tabular}




\section{References}

1. Solow R. We'd better watch out, Times Book Review: New York; 1987 Jul. p. 36.

2. Barua A, Kriebel C, Mukhopadhyay T. Information technology and business value: An analytic and empirical investigation. Information Systems Research.1995; 6(1):3-23.

3. Brynjolfsson E, Hitt LM. Computing productivity: FirmLevel Evidence. The Review of Economics and Statistics. 2003; 85(4):793-808.

4. Brynjolfsson E, Hitt LM. Paradox lost? Firm-level Evidence on the returns to information systems spending. Management Science.1996; 42(4):541-58.

5. Dewan S, Kraemer KL. International Dimensions of the Productivity Paradox. Communications of the ACM. 1998; 41(8):56-62.

6. Dewan S, Kraemer KL. Information technology and productivity evidence from country-level data. Management Science. 2000; 46(4):548-62.

7. Cheng Z, Nault BR. Industry level supplier-driven IT spillovers. Management Science. 2007; 53(8):1199-16.

8. Han K, Kauffman RJ, Nault BR. Research note: Returns to information technology outsourcing. Information Systems Research. 2011; 22(4):824-40.
9. Mittal N, Nault BR. Investments in Information Technology: Indirect effects and information technology intensity. Information Systems Research. 2009; 20(1): 140-54.

10. Tambe P, Hitt LM. The productivity of information technology investments: New evidence from IT Labor Data. Information Systems Research. 2012; 23(3):599-617.

11. Bank of Korea [Internet]. [cited 2016]. Available from: http://www.bok.or.kr/eng/engMain.action.

12. Cho YS, Lee JD, Park CS, Kim TY. Measuring the interindustry spillover of ICT industry's productivity growth. Productivity Review. 2000; 16(3):25-50.

13. Shin YJ. (Three Essays on) Effects of knowledge intensive business service and information technology industry on GDP. Doctoral Thesis, Sogang Business School; 2013.

14. Park, MS, Yim, MS. The effect of team projects on education satisfaction. Indian Journal of Science and Technology. 2016; 9(26):1-9.

15. Vasilenkova NV. Economic interests of national economic entities. Indian Journal of Science and Technology. 2016; 9(26):1-14.

16. Shapovalova IM. Logistical support of interstate trade and economic cooperation. Indian Journal of Science and Technology. 2016; 9(14):1-8. 